\title{
Transit versus Nature. Depreciation of Environmental Values of the Road Alleys. Case Study: Gamerki-Jonkowo, Poland
}

\author{
Marzena Suchocka ${ }^{1, *} \mathbb{0}$, Magdalena Błaszczyk ${ }^{1}{ }^{1}$, Adam Juźwiak ${ }^{2}$, Joanna Duriasz ${ }^{3}$, \\ Adam Bohdan ${ }^{4,5}$ and Jerzy Stolarczyk ${ }^{6}$ \\ 1 Department of Landscape Architecture, Faculty of Horticulture, Biotechnology and Landscape Architecture, \\ Warsaw University of Life Sciences-SGGW, Ul. Nowoursynowska 159, 02-776 Warsaw, Poland; \\ magdalena_blaszczyk@sggw.pl \\ 2 Muzeum Zamkowe w Malborku, Dział Przyrody-Muzeum w Kwidzynie, Starościnska 1, 82-200 Malbork, \\ Poland; adamjuzwiak@gmail.com \\ 3 Ad Natura Joanna Duriasz, Tęczowy Las 2A, 10-687 Bartag, Poland; adnatura@wp.pl \\ 4 Department of Ecology, Faculty of Biology and Environmental Protection, University of Silesia, Bankowa 9, \\ 40-007 Katowice, Poland; adam.bohdan@wp.pl \\ 5 Fundacja Dzika Polska, Teremiski 12, Białowieża 17-230, Poland \\ 6 Eko-trek, Jamnik 1, 55-140 Żmigród, Poland; js@eko-trek.pl \\ * Correspondence: marzena.suchocka@interia.pl; Tel.: +48-506-650-607
}

Received: 16 February 2019; Accepted: 22 March 2019; Published: 26 March 2019

check for updates

\begin{abstract}
Road alleys are multifunctional features in open landscapes that serve as ecological corridors connecting habitats, and play an important role in sustaining ecological stability. However, multiple road authorities claim that tree-lined routes pose a threat to traffic safety and should therefore be removed. This aspect of safety seems crucial to authorities, significantly overwhelming the benefits of road alleys. Problems with the vitality of the trees (which are mainly mature and aging) deliver arguments for cutting them down. The aim of this paper is to examine the environmental and natural value of road alleys based on a $14 \mathrm{~km}$ long section of the Gamerki-Jonkowo Road in the Province of Warmia (Northeast Poland). Further, we aim to verify the degree of hazard posed by trees to be felled for safety reasons. An examination framework with six components was developed for the research. This framework includes a tree risk assessment and vitality evaluation, pulling tests, an examination of the protected hermit beetle and lichen species, and an examination of bat fauna. The results revealed that no trees were in the resignation phase and confirmed that the alley is a unique natural habitat with protected species of lichen, a few bats, and valuable insect species, among others the hermit beetle (Osmoderma barnabita). Therefore, the alley cannot be perceived only as a component of the road infrastructure. The maintenance of the trees seems to be essential when taking into account the environmental stability of the region.
\end{abstract}

Keywords: road alleys; protection of road trees; tree cutting; green infrastructure management; biodiversity conservation

\section{Introduction}

An alley is defined as two rows of trees along both sides of a road, which provide benefits for both people and the environment [1,2]. Suburban development and the popularization of automobiles have caused significant growth in the importance of alleys [3]. Alleys serve as green infrastructure and enhance urban sustainability [1,4]. However, alleys are often a reason for public complaint. Road users are afraid of fallen trees, broken branches, and leaning tree trunks which puts pressure on local 
authorities to cut trees down along the roads and streets [5,6], although the benefits of trees outweigh the annoyances they pose on the whole [7].

Anthropogenic changes in landscape have a bilateral character and can lead to its impoverishment (homogenization) or enrichment (diversification) [8]. Alleys are a type of buffer strip which contribute to the aesthetic of roads [9], as well as increase safety and natural values (biological diversity) [10-12]. They increase ecological capacity and stability too, and further alleviate the climate, in addition to serving as a symbol of cultural identity for the region $[13,14]$. Moreover, trees increase the capacity of the soil to store water, and contribute to carbon sequestration, enhanced local air quality, the removal of PM (particulate matter), local climate regulation, noise interception when planted in dense strips, as well as improve aesthetic quality $[1,15,16]$.

Alleys have a potential to enhance connectivity and ecosystem services, and as such can facilitate forming a network to aid the dispersal and movement of populations [17-26]. Habitat connectivity contributes to ecosystem function and resilience. The migration of many animal species is related to the existence of "connectors" covered by trees and shrubs. Alleys are used as dispersive trails by different animal species, such as insects [27] and birds [28]. They are ecological corridors for the migration of the protected saproxylic beetles and bats, which need them for flight navigation $[29,30]$, as well as forest species, such as the rare and protected dormouse mammals [31].

Old trees are a habitat for endangered and protected lichens [32-36]. Lichens absorb raw materials directly from the air and moisture, which makes them very sensitive to air pollution as there is no way to excrete the pollutants. Therefore lichens have been recognized as indicators of air pollution throughout the world [37,38]. So far, many functional traits of lichens in ecosystems have been recognized, these include: consumption by vertebrates and invertebrates, invertebrates shelter (including gastropods, springtails, mites, beetles, moth larvae and woodlice) $[39,40]$, capturing nutrients from the air (particularly atmospheric $\mathrm{N}_{2}$ ), nutrient concentration, stabilization of water balance and microclimatic conditions, decomposition, rainfall and nutrient interception, microbial abundance and activity, and use as a material for bird's nests [41]. In the study area the most important foliose lichen's functions include: the stabilization of microclimatic conditions, invertebrates feeding on-and shelter provided by-the interface between the lichen thallus and its substrate, and increasing the abundance of invertebrate prey for birds. Drivers of global climate change can potentially have important impacts on lichen communities. More specifically, increased temperature and $\mathrm{N}$ deposition are expected to have adverse effects on many lichen species, and induce large shifts in their functional composition [42]. The presence of large trees is a particularly crucial attribute influencing habitat quality $[43,44]$. Human activities, on the other hand, cause habitat loss. Urban development, including tree removal, produces some of the greatest local extinction rates, and frequently eliminates the large majority of native species, especially because green spaces have become increasingly fragmented, negatively impacting population abundance, genetic variation within species, and species richness [45,46].

Alleys are often an important "link with the past" [47] taking part in the social-ecological resilience of urban and rural areas $[1,2,48]$. They are an inseparable component of the culture in Polish agricultural landscape. In some cases (Warmia, Mazury and Powiśle), the road alleys are even considered as landmarks [49].

Valuing green infrastructure is not only an important requirement in planning for rapidly urbanizing city areas, but also in rural areas [50-52]. In the context of construction and the modernization of road systems, alleys are the component of the landscape most exposed to the effects of human actions. Frequently, management decisions concerning roadside trees are taken precipitately and come down to their felling [53]. Tree management could increase the maintenance costs of roads but potentially contribute to longer-term savings with the provision of a wide range of ecosystem services [54]. Diverse functions such as environmental protection, economic development, and social equity might be an integral part of alleyway management systems [1]. Despite the important contribution to ecosystem services and the general positive attitude towards trees by people (i.e., urban 
dwellers often declare their willingness to pay higher taxes for investment in green infrastructure $[7,54])$, trees are not always accepted due to safety considerations or proximity to road infrastructure $[15,55]$.

Pressure to remove trees along the road has become a serious problem which could threaten their existence in the Polish landscape. Loose rules from the Nature Conservation Act of 2004 gave road managers a large amount of freedom in the decision-making process. As a result, tens of thousands of road trees in Poland were cut down in a "safety battle", in which trees had been perceived as a traffic hazard [56,57]. During road modernization, the protection of trees is rarely implemented, which often causes their decay seeing many trees needing to be felled at a later date. Moreover, road alleys are destroyed, even along the roads that are no longer used, or in farmland (aggregation of agricultural plots related to the extra charge for farmers) where a threat of collision does not exist. Many trees are felled for reasons which lack environmental sense. Road supervisors, who should also take care of tree alleys, do not use a transparent methodology of evaluation or tree classification. The selection of trees to be cut is often inconsiderate and without the support of reliable health condition analysis or risk evaluation. The compromise between risk and biodiversity is a challenge for road managers, and forestry service markets do not fully support multifunctional aims [58]. Meanwhile, researchers point out that there is a possibility to avoid the cutting of old road alleys and ensure traffic safety at the same time [59-61]. Urban forests provide a habitat for wildlife such as bats, protected insects or cavity-nesting birds that colonize the dead and decayed stems and branches of trees. The same dead and decayed stems and branches are the most common defect and are perceived by road managers as having a greater likelihood of failure, which increases risk. But in a study of Kanea [62], the vast majority of trees with decayed stems and branches had moderate or low risk.

Tree safety management should balance the benefits of risk reduction with the associated costs, in terms of both lost tree value and financial costs. The concept of acceptable risk has been proposed by Paine [63], Helliwell [64], as well as Matheny and Clark [65]. Ellison [66] extended tree risk assessment by allocating quantifiable values to the probability of failure and the impact potential of trees, and to targets on which trees might fail. In our study we adopted the VTA method for tree risk assessment, built on a similar base, but considering bio-mechanics to provide risk diagnosis for the prevention of accidents [67]. Risk assessment methods are adopted in the form of standards, such as, for example, Baumkontrollrichtlinien in Germany, developed by FLL (Forschungsgesellschaft Landschaftsentwiclung Landschaftsbau e.V.), one of the professional associations [68,69].

The above mentioned methods assume an evaluation of the probability of failure by hazard rating and depend on the specific tree. Risk mitigation measures are performed, e.g., proper pruning, lowering speed of vehicle or educational actions. Proper roadside tree management could lead to a reduction of hazards through inspection and mitigation, maintaining the level of hazard at an acceptable level with the need to keep large, beautiful trees in situ [70]. The collision of vehicles with trees is the reason for $5.1 \%$ of road accidents, which is rather minor compared to other causes [71]. The main reason for accidents is drivers exceeding speed limits [72,73]. In fact, many researchers point out that trees alongside streets and roads contribute to an increase in the safety level [74-77]. Trees are responsible for causing "an immunization effect" and being a stress inhibitor for drivers [78,79]. They help drivers regain a balance after a stressful reaction to a situation stimulus and provide higher frustration tolerance, making road users drive slower and more carefully $[80,81]$. The above-mentioned facts and circumstances have contributed to research concerning the validity of removing road alleys. Verification of the degree of hazard posed by road trees designated for cutting due to safety concerns, and the assessment of their environmental values was set as the aim of the paper. It is assumed that it is possible to reconcile the safety requirements to nature protection by the application of objective methods for the management of road trees. 


\section{Case Study}

\subsection{Study Area}

In this study a section of road planted with trees, which in the opinion of the road manager should be cut due to risk and lack of value, was examined. Analyses were developed in order to verify the necessity of the planned cutting of 28 trees that was unsubstantiated by a reduction of traffic threats. There was also a plan to remove the whole alley in the future in order to modernize the above-mentioned section of the road [82]. The survey was executed on the Gamerki-Jonkowo section, county road number 26124 (Jonkowo district, Warmińsko-Mazurskie Province, Northeast Poland). This fragment lies within and connects several areas of conservation. On the Gamerki-Kawkowo section of road it crosses OSOP Dolina Pasłęki PLB280002 and it runs nearby OOS Dolina Pasłęki PLH280006 where the beetle Osmoderma barnabita was indicated as a protected species. In Jonkowo Kolonia town the road is located just next to the OOS Buczyny Warmińskie PLH280033 and Kamienna Góra nature reserve. Within the reserve, there lies a natural beechwood old-growth forest [49] that became a potential habitat for Osmoderma barnabita. The investigated area crosses the ecological corridor of Dolina Pasłęki on the road section Gamerki-Kawkowo Nowe (Figure 1). Morover, the Gamerki-Jonkowo alley has been "a bone of contention" for Poviat Road Services (Powiatowa Służba Drogowa) who have "sentenced" the alley of trees to be cut down while local activists have attempted to protect them.

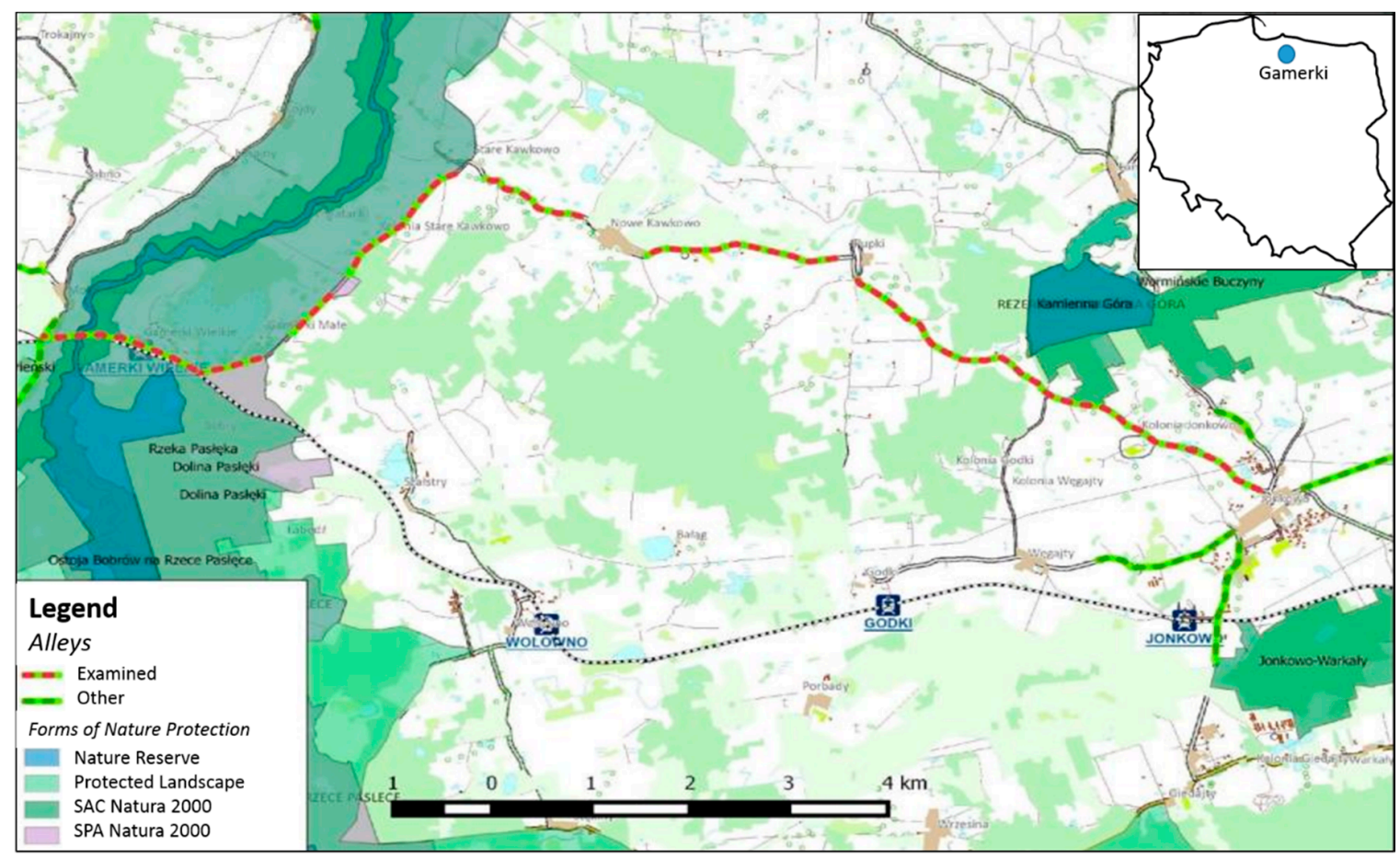

Figure 1. Research area. Gamerki-Jonkowo road alley with neighboring forms of nature protection.

Discussed linear tree plantations are present in 7 segments with a total length of ca. $12.4 \mathrm{~km}$ along the road that counts ca. $14 \mathrm{~km}$. At the same time this road trees segment account for ca. $25 \%$ of all alleys in the area of the whole Jonkowo district. The old-growth forest occurs in whole space in between a traffic lane and a ditch. The appearance of lichens on the counterscarp is the result of natural succession. The distance between trees in the segment is ca. 6-8 m. The tree alley is dense with gaps but there are some sections which have been thinned (Figure 2). 


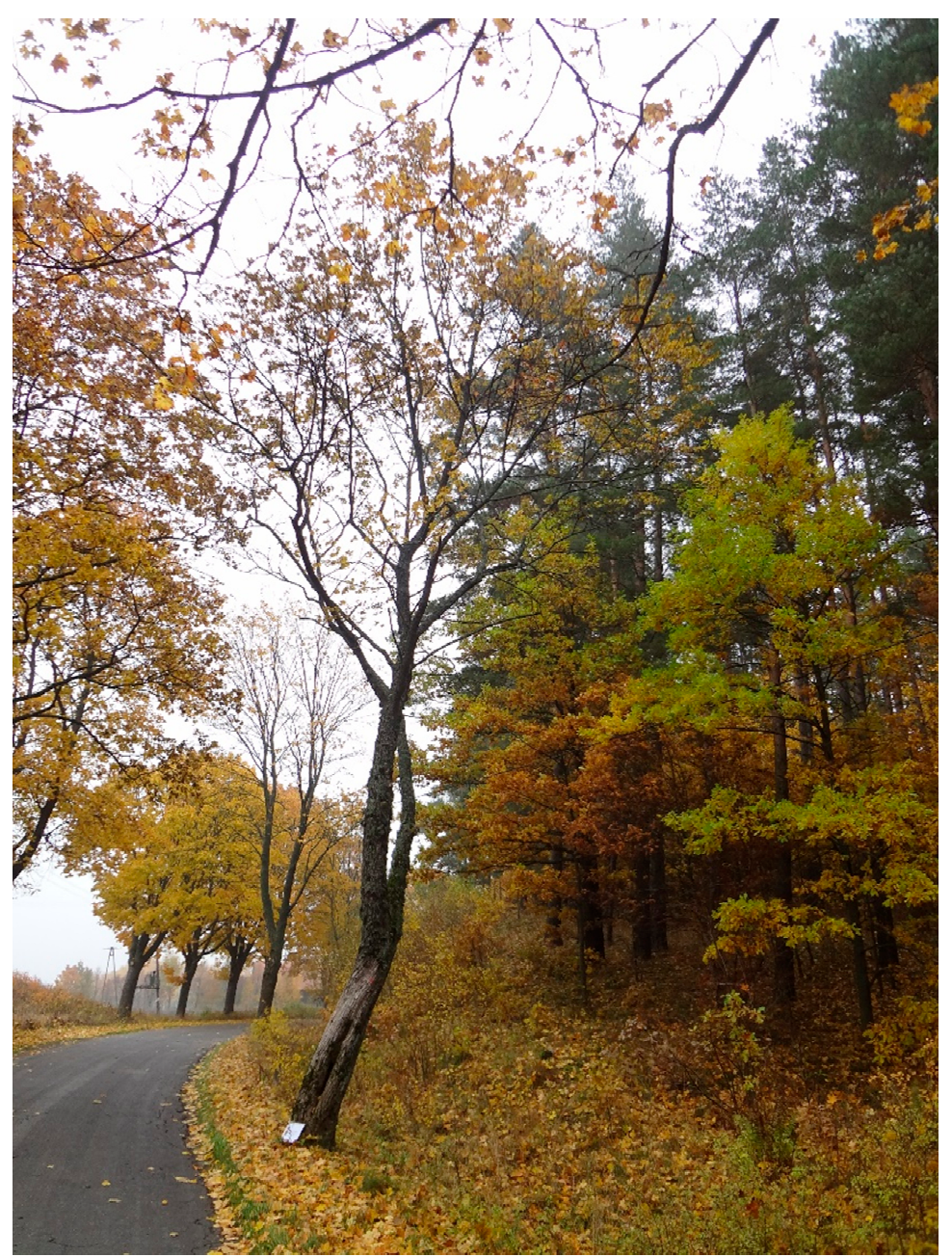

Figure 2. Gamerki-Jonkowo road alley.

Modernization works on the area of interest have been planned in order to improve the standards of traffic safety (including surface modernization). The cutting of the 28 trees was planned because of the modernization. The road supervisor planned the removal of the whole alley (more than 1500 trees) in the future. In their opinion, trees threaten traffic safety and thus the value of the alley is low. However, such an attitude towards trees raises many doubts when taking into consideration actual knowledge concerning the potential benefits of alleys, and directly contributed to initiating this research.

\subsection{Methods}

Alleys serve as ecological corridors, and therefore their value must be estimated taking into account both "flora and fauna". As linear objects, alleys are particularly important for two species: bats and hermit beetles [83-85]. They use alleys as places for living, breeding, feeding, resting, hiding, navigating etc. The continuity of the alleys is crucial for maintaining local populations of these species.

While developing methods of investigation, two aspects were taken into consideration: safety evaluation and environmental-ecological evaluation of the alley. An evaluation of the alley was made based on a "standard, but detailed" examination (risk assessment with pulling tests, and vitality examination). However, it is worth mentioning that the results of these investigations may not have an outcome with respect to the legal protection of the trees. In other words, "even vital trees may be felled, if the pressure for removal is high". Therefore, factors determining the legal protection of trees (as habitats of valuable species) were taken into account in the environmental-ecological valuation. 
The evaluation was made for three species: lichens, bats, and hermit beetles. Other important functions and ecological criteria (such as e.g., micro-climatic function, air purification, biodiversity promotion) were not used as they are implemented as forms of protection in the Polish law.

The six methods used in the research include: safety evaluation (VTA method and pulling tests), vitality evaluation, and an examination of lichen, bat fauna and hermit beetle as protected species (Figure 3).

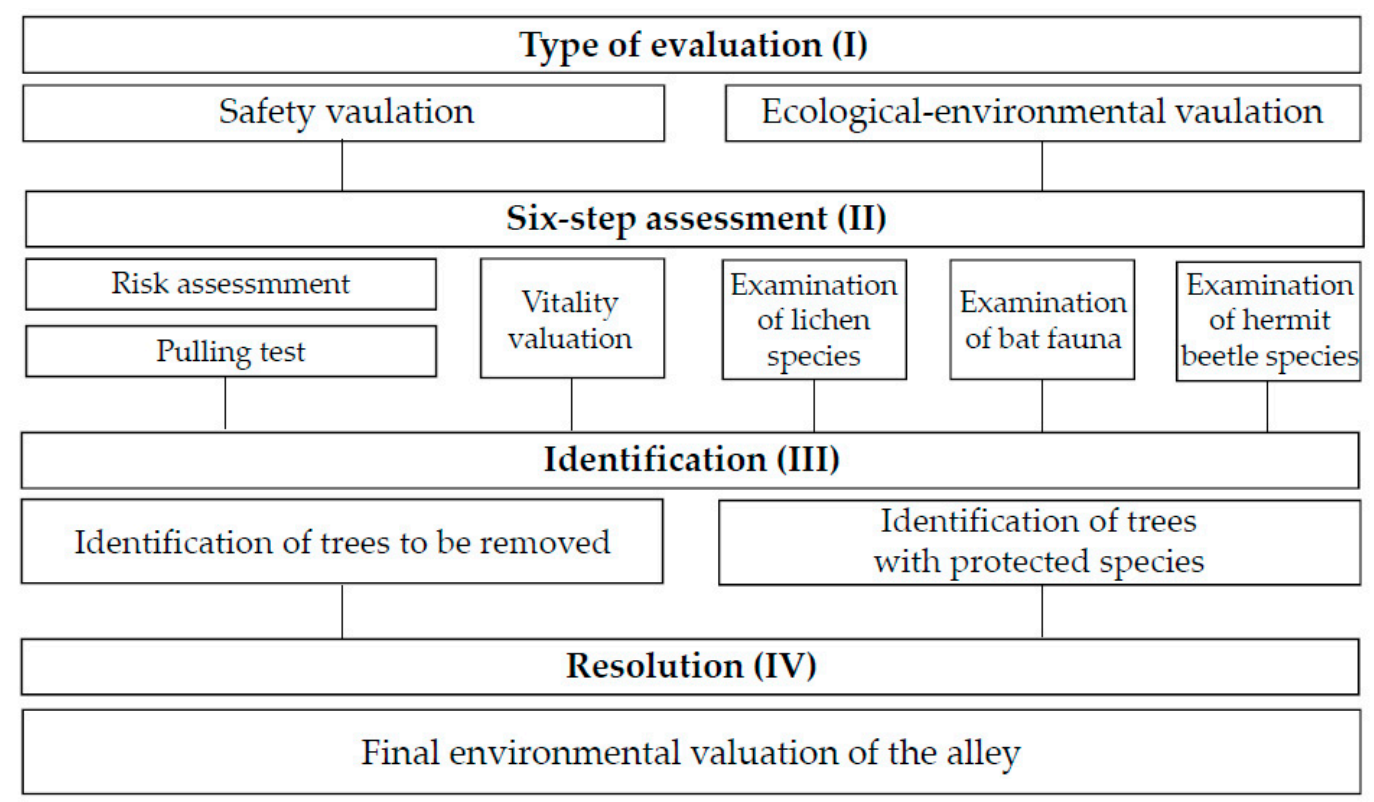

Figure 3. Methodological framework and the general phases of the research.

\section{Safety Evaluation}

1. Risk assessment, verifying the statistics from the VTA method (Visual Tree Assessment) was used for 28 trees chosen for removal. Trees were examined by visual evaluation and segregated into different risk classes, according to the quantitative risk assessment typology formulated by ISA (International Society of Arboriculture). According to the ISA recommendation each tree should be categorized into one of the five classes indicating risk: insignificant (A), low (B), moderate (C), high (CD), extreme (D). In the case of every tree assessment, safety measures were recommended and performed according to the standard safety procedure, as a result of the VTA method investigation [86]. To evaluate trees for hazard, the VTA method takes into account such factors as occupancy, exposition to the wind, evaluation of the target, site consideration, damage to root system, assessment the extent of decay in trees and tree structural defects. On the basis of the assessment, safety measures are recommended, with an aim to reduce the tree risk to an acceptable level $[67,87]$.

It's worth underlining that an expert tree risk assessment can be influenced by risk perception, risk acceptance, and professional bias $[53,88]$. The decision for which level of risk a tree presents depends on the expert and his/her knowledge and experience. In case of doubts, additional instrumental investigation, e.g., Pulling test, is used.

2. Pulling tests of two trees from the group designated to be cut down were taken. These trees were designated as posing a risk, on the basis of the results of VTA method. The pulling test was conducted according to the TSE methodology (Tree Stability Evaluation) developed by the ITEG group (Independent Tree Expert Group). Among the other tests, there were also measurements of fracture resistance and an evaluation of root stability in the soil. The pulling test is a complementary method, used in practice as a source of additional information, needed as a verification in the decision making process in case of insufficient conclusions of the VTA method investigation [89]. 
3. Vitality evaluation was done for each tree according to Rollof's classification that is based on distal crown parts liveliness. In total, 28 trees chosen for removal were segregated into four groups: 0 'exploration' where the tree is in the phase of intensive offshoot growth; 1 'degeneration' where the tree has slightly delayed offshoot growth; 2 'stagnation' where the tree has visibly delayed offshoot growth; 3 'resignation' where the tree is dying, without regeneration possibility nor able to return to the second class [90].

\section{Ecological-environmental Valuation}

4. The protected lichen species were examined on the 28 selected trees chosen for removal. The examination was conducted in the middle of November 2015 according to the vegetation inventory [91]. Lichen species protected strictly or partially were included in regulation by the Ministry of the Environment from 9 October 2014 when species of fungi were inventoried on a number of trees. Species were defined on the basis of morphological traits, and counted on every tree. Trees with a trunk surface and tree branch to the height of $5 \mathrm{~m}$ above the ground were chosen for investigation. In order to detect the lichen, a $3.5 \mathrm{~m}$ high ladder was used.

5. The bat fauna was examined along the whole tree alley section. The examination was conducted using an ultra sound detector between 25 August and 16 September 2015. The research took place along the whole alley from the bridge on the Pasłęka River, Gamerek Wlk. neighborhood, as far as the rail crossing at Wiliamów. The research was conducted during peak hours of bat activity in the evening, starting approximately 30 minutes after sunset and lasting around 4 hours. Recordings were made from within a car driving at ca. $4.5 \mathrm{~km} / \mathrm{h}$. Detection was carried out using Petersson D230 and Petersson D240 $\mathrm{x}$ detectors. The recorded material was analyzed by computer analysis (Bat sound program, Petersson Electronic Company). In addition to the evening reading, the bats sounds were also recorded during the morning on 25 August 2015. The alley was observed in order to determine the occurrence of breeding colonies. As within the alley, there were also recognized trees which are known to support bat habitats.

The alley was divided into a number of sections, depending on a unified landscape type and the presence of certain structures and bat habitats. The length of sections varied form $350 \mathrm{~m}$ to $1000 \mathrm{~m}$ (Figure S1). The bat activity index was calculated for every section according to the following formula:

$$
\mathrm{Ix}=\mathrm{Lx} * 60 / \mathrm{T}
$$

where:

$\mathrm{Ix}=$ activity index for a group of species " $\mathrm{x}$ ";

$\mathrm{Lx}=\mathrm{a}$ number of all the recorded bat activities in sections

$\mathrm{T}=$ time of all the records (in minutes)

The index describes the number of bat fly-overs in every section within an hour. The following activity levels were assumed:

0-20 signals per hour: low activity

21-40 signals per hour: medium activity

41-60 signals per hour: high activity

above 60 signals per hour: very high activity

6. We performed an inventory of the hermit beetle Osmoderma barnabita on the whole road section. The examination was conducted according to the standard methodology that is recommended for this species inventory [17] by performing the following:

- a search for larval excrements and the remains of the hermit beetle imago's shells within trees (hollow and surroundings): 19 August-13 November 2015; 
- observation of imago stage using pheromones traps: 19 August-30 August 2015;

- observation of adult beetles in the tree cavities surroundings: 19 August-30 August 2015;

- observation of imago in the tree hollow interior with usage of endoscopic camera connected to the computer: 19 August-20 August 2015.

Conclusions from the survey were used to estimate the environmental value of Gamerki-Jonkowo road section and the validity of tree removal.

A final environmental evaluation of the results constitutes a synthesis of the safety evaluation and the ecological-environmental evaluation.

\section{Results}

\subsection{Characteristic of Investigated Alley Trees}

The tree alley is created by the following species: Norway Maple (Acer platanoides L.) $-60 \%$, Small-leaved Lime (Tilia cordata L.) —27\%, Silver Birch (Betula pendula L.) —6\%, Horse Chestnut (Aesculus hippocastanum L.) - 3\%, European Ash (Fraxinus excelsior L.) -3\%, English Oak (Quercus robus) -1 \% (Figure S1). Additional species were also found in the old-growth forest composition: Common Aspen (Populus tremula), Sycamore Maple (Acer pseudoplatanus) and the apple tree (Malus domestica). The avenue consists of ca. 1900 trees in total.

In addition, there are also seedlings of the aformentioned species and additionally: Scots Pine (Pinus silvestris), Goat Willow (Salix caprea L.), European Elder (Sambucus nigra), Common Hazel (Corylus avellana), Rowan (Sorbus aucuparia), Common Hornbeam (Carpinus betulus), Blackthorn (Prunus spinosa L.), Black Cherry (Prunus serotina), Single-seeded Hawthorn (Crataegus monogyna), Rose (Rosa sp.), Common Snowberry (Symphoricarpos albus), White Pine (Pinus strobus), Northern White Cedar (Thuja occidentalis), Staghorn Sumac (Rhus typhina), european Spindle (Euonymus europaeus), Scots Elm (Ulmus montana) and Common Lilac (Syringa vulgaris).

Trunk circumference was measured at a height of $1.3 \mathrm{~m}$ and results were in the range of 100-350 cm. The average trunk circumference is $190 \mathrm{~cm}$. There are also specimens of Small-leaved Lime whose trunk circumferences met the criteria for being considered as a natural monument. According to the Polish Nature Protection Act, natural monuments refer to magnificent trees with a special natural, scientific, cultural, and historical or landscape value and possess individual features, distinguishing them among others.

\subsection{Risk Assessment}

In total, 28 trees were selected by road services to for removal because of the threats and weak vitality evaluated in the study. The trees are: 13 Norway Maples (Acer platanoides), 10 Small-leaved Limes (Tilia cordata) and five English oaks (Quercus robur). The evaluation indicated the occurrence of $25 \%$ trees in B class, $29 \%$ of trees in C class and $46 \%$ of trees in CD class. Some trees in C and CD class demanded risk minimization by tree crown stabilization (11 trees) and dry branch removal ( 8 trees) (Table 1).

\subsection{Pulling Tests}

There were two trees which after preliminary testing appeared unsafe. These trees were verified by conducting a pulling test. Tree static examinations were conducted according to the loading method and trunk fraction resistance. The survey concerned a Small-leaved Linden (Tilia cordata Mill.), No. 4 (Figure 4), and the Small-leaved Linden (Tilia cordata Mill.) No. 5 (Figure 5). 
Table 1. Dendrological examination of trees dedicated to cut because of safety reasons VTA on the Gamerki Wielkie-Nowe Kawkowo road section with safety recommendation.

\begin{tabular}{|c|c|c|c|c|c|c|}
\hline No & Species & $\begin{array}{l}\text { Trunk Circum- } \\
\text { Ference at } \\
130 \mathrm{~cm} \text { Height }\end{array}$ & $\begin{array}{l}\text { Classes of } \\
\text { Risk } \\
\text { Tendency }\end{array}$ & $\begin{array}{c}\text { Rollof's } \\
\text { Classification }\end{array}$ & $\begin{array}{c}\text { Safety } \\
\text { Recomendations }\end{array}$ & $\begin{array}{c}\text { Inventory of } \\
\text { Hermit Beetle } \\
\text { (Osmoderma } \\
\text { barnabita) }\end{array}$ \\
\hline 1 & 2 & 4 & 3 & 5 & 6 & 7 \\
\hline 1 & Tilia cordata & 340 & $\mathrm{C}$ & 0 & binding of stems & presence \\
\hline 2 & Acer platanoides & 137 & $\mathrm{C}$ & 1 & deadwood cutting & \\
\hline 3 & Tilia cordata & 238 & B & 0 & - & presence \\
\hline 4 & Tilia cordata & 317 & $\mathrm{CD}$ & 0 & $\begin{array}{l}\text { pulling } \\
\text { test-583\% }\end{array}$ & \\
\hline 5 & Tilia cordata & 298 & $\mathrm{CD}$ & 1 & $\begin{array}{c}\text { pulling } \\
\text { test-264\% }\end{array}$ & \\
\hline 6 & Tilia cordata & 316 & $C D$ & 0 & binding of stems & \\
\hline 7 & Tilia cordata & 336 & $\mathrm{C}$ & 0 & - & \\
\hline 8 & Acer platanoides & 272 & B & 1 & - & \\
\hline 9 & Acer platanoides & 270 & $\mathrm{CD}$ & 1 & $\begin{array}{l}\text { binding of the } \\
\text { branch, } \\
\text { retrenchment } \\
\text { pruning } \\
\text { binding of three }\end{array}$ & \\
\hline 10 & Acer platanoides & 272 & $\mathrm{CD}$ & 0 & $\begin{array}{l}\text { codominant stems, } \\
\text { retrenchment } \\
\text { pruning }\end{array}$ & \\
\hline 11 & Acer platanoides & 197 & B & 1 & $-{ }^{2}-{ }^{-}$ & \\
\hline 12 & Acer platanoides & 149 & B & 1 & - & \\
\hline 13 & Acer platanoides & 300 & $\mathrm{CD}$ & 1 & $\begin{array}{l}\text { binding of the } \\
\text { branch, } \\
\text { deadwood cutting }\end{array}$ & \\
\hline 14 & Acer platanoides & 170 & C & 0 & - & \\
\hline 15 & Tilia cordata & 368 & $\mathrm{CD}$ & 0 & $\begin{array}{l}\text { binding of the } \\
\text { codominant stems }\end{array}$ & \\
\hline 16 & Acer platanoides & 237 & $\mathrm{CD}$ & 1 & deadwood cutting & \\
\hline 17 & Quercus robur & 315 & $\mathrm{CD}$ & 2 & $\begin{array}{l}\text { binding of the } \\
\text { codominant stems }\end{array}$ & \\
\hline 18 & Tilia cordata & 458 & C & 1 & $\begin{array}{l}\text { binding of the } \\
\text { branch }\end{array}$ & \\
\hline 19 & Acer platanoides & 210 & C & 1 & $\begin{array}{l}\text { binding of the } \\
\text { codominant stems } \\
\text { binding of the }\end{array}$ & \\
\hline 20 & Acer platanoides & 250 & $\mathrm{CD}$ & 2 & $\begin{array}{c}\text { branch, } \\
\text { deadwood cutting }\end{array}$ & \\
\hline 21 & Acer platanoides & 207 & B & 1 & - & \\
\hline 22 & Acer platanoides & 224 & B & 1 & - & \\
\hline 23 & Acer platanoides & 184 & $\mathrm{CD}$ & 2 & deadwood cutting & \\
\hline 24 & Acer platanoides & 277 & $\mathrm{CD}$ & 1 & $\begin{array}{l}\text { binding of the } \\
\text { codominant stems }\end{array}$ & \\
\hline 25 & Acer platanoides & 205 & $\mathrm{C}$ & 2 & deadwood cutting & \\
\hline 26 & Acer platanoides & 195 & B & 1 & - & \\
\hline 27 & Acer platanoides & 253 & $\mathrm{CD}$ & 1 & deadwood cutting & \\
\hline 28 & Quercus robur & 324 & $\mathrm{C}$ & 1 & - & \\
\hline
\end{tabular}




\begin{tabular}{|c|c|c|c|c|c|}
\hline \multicolumn{2}{|c|}{ Project: Stare Kawkowa lipa nr 4 XII 2015} & \multicolumn{2}{|c|}{ Tree No. Stare Kau Report No. 1} & \multicolumn{2}{|c|}{ e: 2015-12-15 Inspector: Jerzy Stolarczyk } \\
\hline & \multirow{12}{*}{ 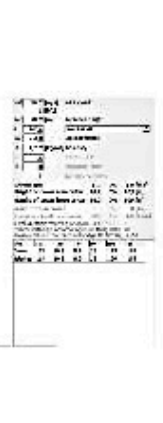 } & Location: & Free landscape hilly & Tree height & $18 \mathrm{~m}$ \\
\hline & & Terrain exponent: & 0,17 & D trunk: & $101 \mathrm{~cm}$ \\
\hline & & Height laminar wind layer: & $290 \mathrm{~m}$ & Crown area: & $119 \mathrm{~m}^{2}$ \\
\hline & & Species: & Tilia cordata & Wirdspeed force center: & $35,49 \mathrm{~m} / \mathrm{s}$ \\
\hline & & Yield strength u. comp.: & $2 \mathrm{kN} / \mathrm{cm}^{2}$ & Wind gust factor: & 1,2 \\
\hline & & Elasticity limit: & $0,24 \%$ & Tree swinging factor: & 1,4 \\
\hline & & Drag coefficient: & 0,25 & Air pressure: & $1000 \mathrm{mb}$ \\
\hline & & Force center: & $10.9 \mathrm{~m}$ & Air temperature: & $5{ }^{\circ} \mathrm{C}$ \\
\hline & & Height dummy load: & $3,5 \mathrm{~m}$ & Air density: & $1,25 \mathrm{~kg} / \mathrm{m}^{3}$ \\
\hline & & Anchar point distance: & $13 \mathrm{~m}$ & Bending moment: & $250,89 \mathrm{kNm}$ \\
\hline & & Anchor height correction: & $0 \mathrm{~m}$ & Crown area a. pruning: & $119 \mathrm{~m}^{2}$ \\
\hline & & & & Force center a. pruning: & $10,9 \mathrm{~m}$ \\
\hline
\end{tabular}
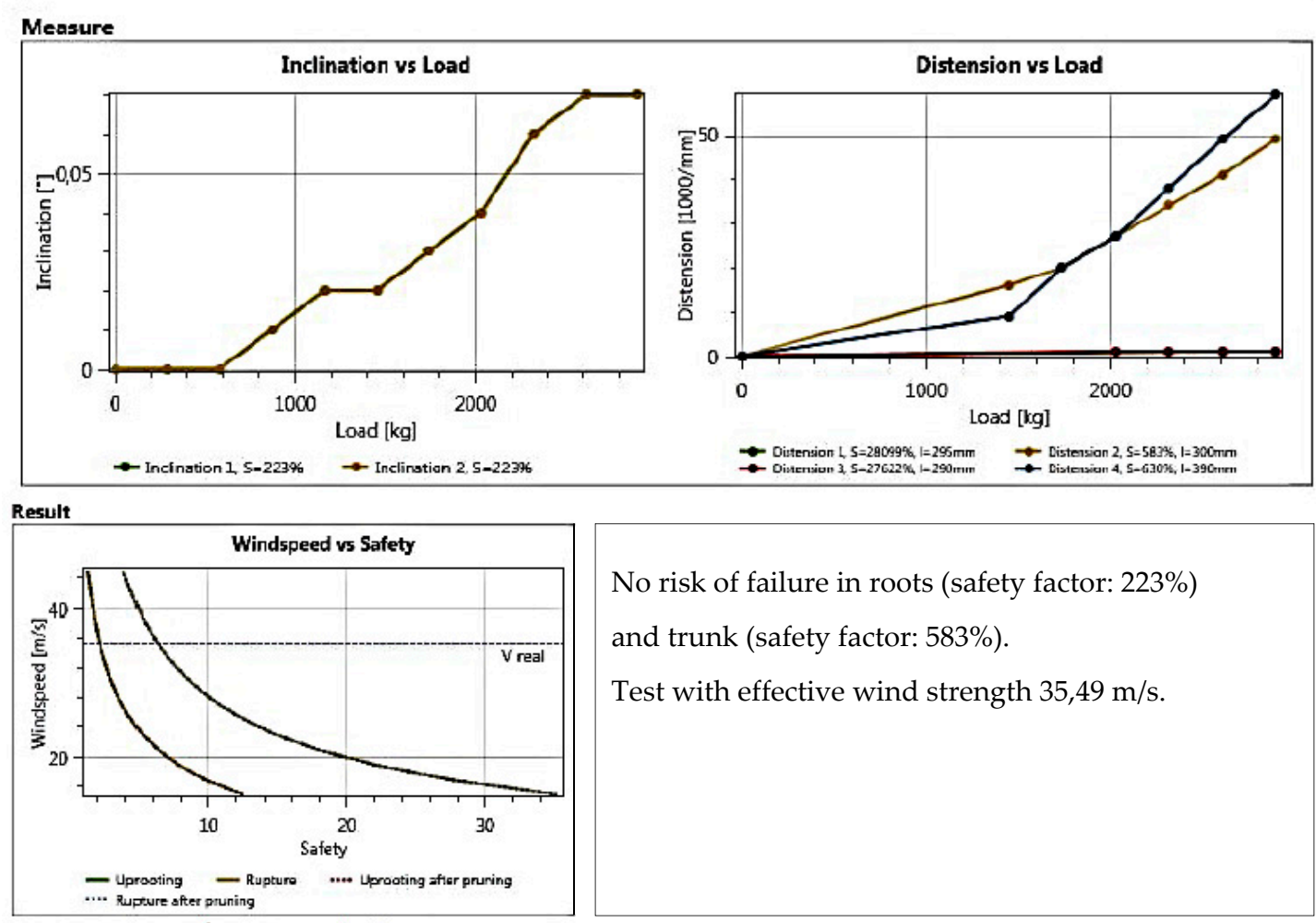

Figure 4. Tilia cordata no. 4/13-pulling test report.

The loading test was conducted on selected Small-leaved Lindens. It proved that the trees demonstrated over-regular stability in the ground. Inclinometers placed on the trunk describing tree stability showed the level of: Linden No. 4-223\%, Linden No. 5-347\% (safety level is considered as higher than 150\%). Elastometer indicators were verified. On the weakest parts of the trunks (with the biggest defects) sensors indicated following results: Linden No. 4-583\%, Linden No. 5-264\%. This proves sufficient breaking resistance for the trees to remain in situ. 


\begin{tabular}{|c|c|c|c|c|c|}
\hline Project: Stare Kawkor & $5 \times 12015$ & Tree No. Stare Kaw Report & No. 2 & 15-11-05 Inspector: Jerz & y Stolarczyk \\
\hline & & Location: & Free londscape hilly & Tree height: & $18 \mathrm{~m}$ \\
\hline & & Terrain exponent: & 0,17 & D trunk: & $95 \mathrm{~cm}$ \\
\hline & & Height laminar wind layer: & $290 \mathrm{~m}$ & Crown area: & $83 \mathrm{~m}^{2}$ \\
\hline & 90 & Species: & Tilia cordata & Windspeed force center & $35,87 \mathrm{~m} / \mathrm{s}$ \\
\hline & $-1=$ & Yield strength $\mathbf{u}$ comp.: & $2 \mathrm{kN} / \mathrm{cm}^{3}$ & Wind gust factor: & 1,2 \\
\hline & $\exists=:$ : & Elasticity limit: & $0,24 \%$ & Tree swinging factor: & 1,4 \\
\hline & mating & Drag coefficient & 0,25 & Air pressure: & $1000 \mathrm{mb}$ \\
\hline & & Force center: & $11,6 \mathrm{~m}$ & Air temperature: & $9^{\circ} \mathrm{C}$ \\
\hline & & Height dummy load: & $7 \mathrm{~m}$ & Air density: & $1,23 \mathrm{~kg} / \mathrm{m}^{3}$ \\
\hline & & Anchor point distance: & $24,5 \mathrm{~m}$ & Bending moment: & $187,52 \mathrm{kNm}$ \\
\hline & & Anchor height correction: & $0 \mathrm{~m}$ & Crown area a. pruning: & $83 \mathrm{~m}^{2}$ \\
\hline & & & & Force center a, pruning: & $11,6 \mathrm{~m}$ \\
\hline
\end{tabular}
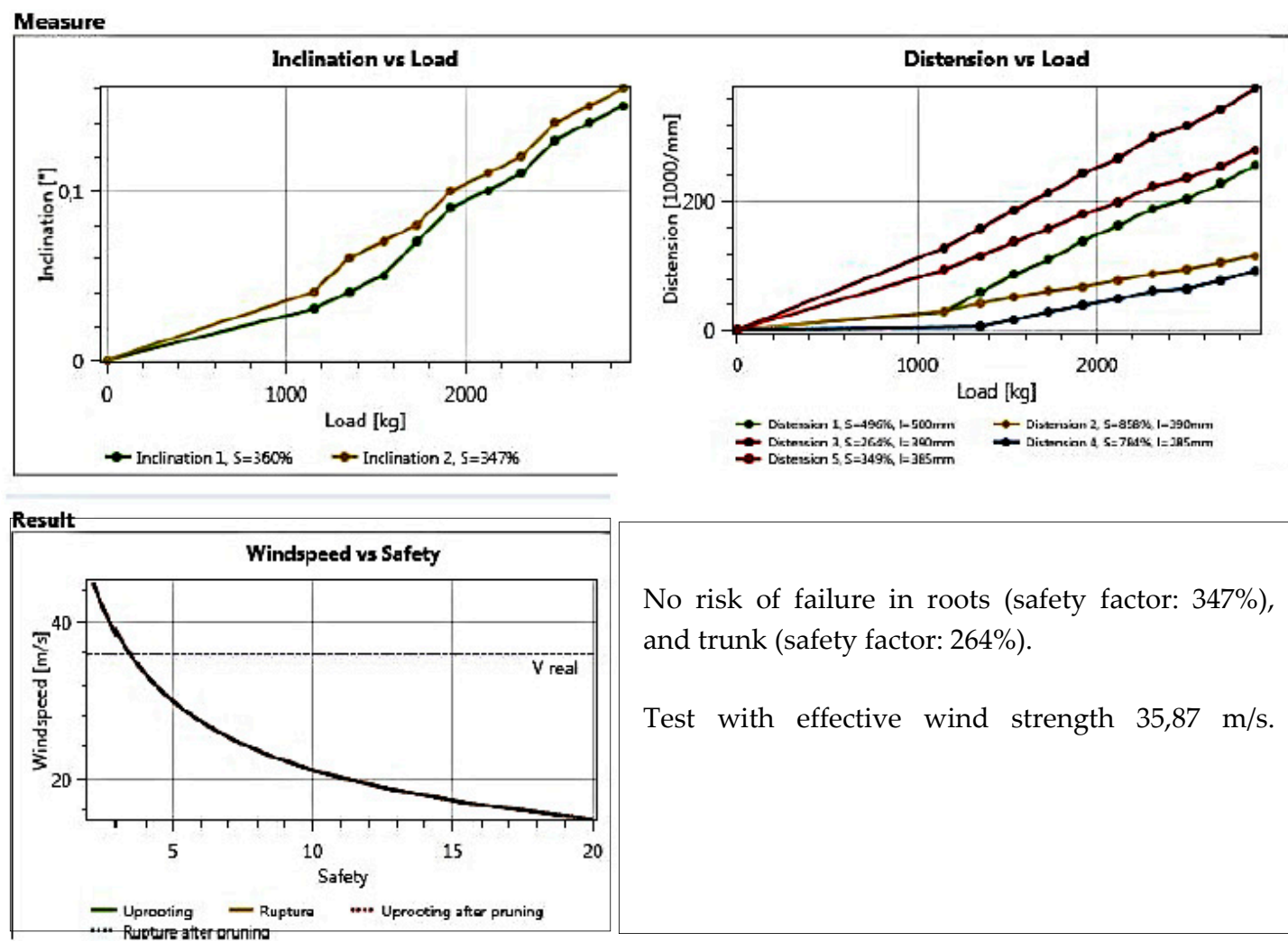

No risk of failure in roots (safety factor: $347 \%$ ), and trunk (safety factor: $264 \%$ ).

Test with effective wind strength $35,87 \mathrm{~m} / \mathrm{s}$.

Figure 5. Tilia cordata no. 5/13-pulling test report.

\subsection{Vitality Evaluation}

According to the Rollof's classification, there were no trees in the resignation phase (3rd class) of the evaluated group. A total of $29 \%$ of the trees were qualified to the exploration phase ( 0 class). The percentage distribution of trees in others groups (degeneration and stagnation) amounted to $57 \%$ and $14 \%$, respectively, which demonstrates that $86 \%$ of examined trees were in good health (Table 1 ).

\subsection{Examination of Lichen Species}

A survey of lichen species under protection was taken on the sample of 28 trees. It demonstrated the occurrence of 2837 specimens of epiphytic lichens of 9 different species (Tables 2 and 3). 
Table 2. Species of lichens observed on the studied trees. EN—dying; VU—exposed.

\begin{tabular}{ccc}
\hline Name & Protection Status & $\begin{array}{c}\text { Status in the Red List of Extinct or } \\
\text { Threatened Lichens in Poland [32] }\end{array}$ \\
\hline $\begin{array}{c}\text { Usnea hirta } \\
\text { Melanohalea elegantula }\end{array}$ & $\begin{array}{c}\text { partial protection } \\
\text { strict protection } \\
\text { Ramalina pollinaria }\end{array}$ & \\
partial protection & VU \\
Ramalina fraxinea & strict protection & EN \\
Ramalina farinacea & strict protection & EN \\
Pleurosticta acetabulum & partial protection & VU \\
Parmelina tiliacea & partial protection & EN \\
Hypogymnia tubulosa & strict protection & \\
\hline
\end{tabular}

Table 3. The number of lichen species on proven trees growing on trees in the $14 \mathrm{~km}$ road lane of the Gamerki Wielkie-Jonkowo route: 2837 individuals belonging to 9 species of lichens subject to legal protection (Ap-Acer platanoides, Qr-Quercus robur, Tc-Tilia cordata, A-40\% on a dry branch, B-15\% on a dry branch, $\mathrm{C}$-on a dead wood, $\mathrm{L}$-left, $\mathrm{R}$-right).

\begin{tabular}{|c|c|c|c|c|c|c|c|c|c|c|c|c|}
\hline$\dot{z}$ & 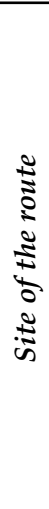 & 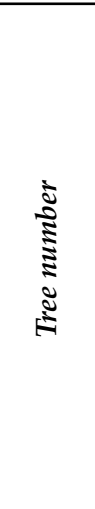 & 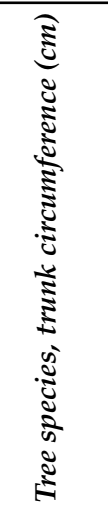 & 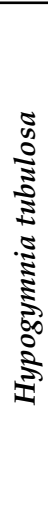 & 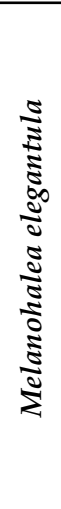 & 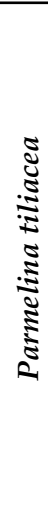 & 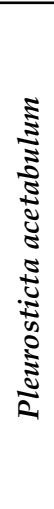 & 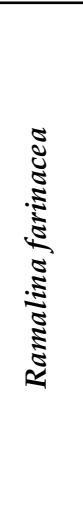 & 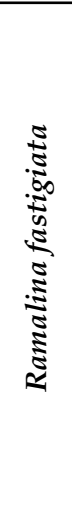 & 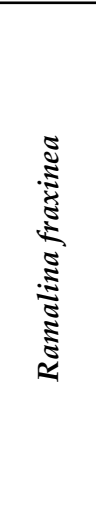 & 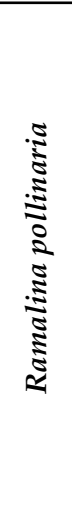 & 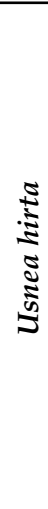 \\
\hline 1 & $\mathrm{~L}$ & $1 / 13$ & Tc340 & & & & & 2 & & & & \\
\hline 2 & $\mathrm{R}$ & $2 / 13$ & Ap137 & & & & 8 & 30 & 10 & 80 & & \\
\hline 3 & $\mathrm{~L}$ & $3 / 13$ & Tc238 & & & & & & & & & \\
\hline 4 & $\mathrm{R}$ & $4 / 13$ & Тс317 & & 15 & 5 & & & & & & \\
\hline 5 & $\mathrm{R}$ & $5 / 13$ & Tc298 & & & & & 4 & & 1 & & \\
\hline 6 & $\mathrm{~L}$ & $6 / 13$ & Тс316 & & 30 & & 5 & 20 & & 5 & 15 & \\
\hline 7 & $\mathrm{~L}$ & $7 / 13$ & Тc336 & & & & 3 & 1 & & 1 & & \\
\hline 8 & $\mathrm{~L}$ & $9 / 13$ & Ap272 & 5 & & & & 40 & 15 & 40 & 100 & \\
\hline 9 & $\mathrm{R}$ & $10 / 13$ & Ap231 & & & & & 150 & 30 & 30 & 70 & \\
\hline 10 & $\mathrm{~L}$ & $11 / 13$ & Ap197 & & & & & 40 & 20 & $100 \mathrm{~A}$ & 30 & \\
\hline 11 & $\mathrm{R}$ & $12 / 13$ & Ap149 & & & & 15 & 50 & 60 & $120 \mathrm{~B}$ & & \\
\hline 12 & $\mathrm{~L}$ & $8 / 13$ & Ap272 & & & & & 180 & 3 & 12 & & \\
\hline 13 & $\mathrm{~L}$ & $21 / 13$ & Ap207 & & & & & 180 & 15 & 20 & 4 & 60 \\
\hline 14 & $\mathrm{~L}$ & $13 / 13$ & Ap300 & & & & 5 & 15 & 10 & 80 & & \\
\hline 15 & $\mathrm{~L}$ & $14 / 13$ & Tc170 & & & & 25 & & 50 & & & \\
\hline 16 & $\mathrm{R}$ & $15 / 13$ & Ap368 & & & & & 10 & 20 & 2 & & \\
\hline 17 & $\mathrm{R}$ & $16 / 13$ & Qr237 & & & & 3 & 20 & 10 & 30 & & \\
\hline 18 & L & $17 / 13$ & Tc315 & & & & 12 & 130 & 7 & 10 & & \\
\hline 19 & $\mathrm{~L}$ & $18 / 13$ & Ap458 & & & & & 3 & 2 & 1 & 4 & \\
\hline 20 & $\mathrm{~L}$ & $19 / 13$ & Ap210 & 1 & & & & 150 & 20 & 25 & & \\
\hline 21 & $\mathrm{~L}$ & $20 / 13$ & Ap250 & & & & 2 & 15 & 30 & 15 & 10 & \\
\hline 22 & $\mathrm{R}$ & $22 / 13$ & Ap224 & & & & & 30 & 16 & 10 & & \\
\hline 23 & $\mathrm{R}$ & $23 / 13$ & Ap184 & & & & & 50 & 15 & 30 & & \\
\hline 24 & $\mathrm{~L}$ & $24 / 13$ & Ap277 & & & & 3 & $80 \mathrm{~A}$ & $10 \mathbf{B}$ & 15 & $50 \mathrm{C}$ & \\
\hline 25 & $\mathrm{~L}$ & $25 / 13$ & Ap205 & & & & 15 & 30 & 30 & 15 & 30 & \\
\hline 26 & $\mathrm{R}$ & $26 / 13$ & Ap195 & 5 & & & & & 15 & 15 & & \\
\hline 27 & $\mathrm{R}$ & $27 / 13$ & Ap253 & & & & 20 & 9 & 10 & 25 & 10 & \\
\hline 28 & $\mathrm{~L}$ & $28 / 13$ & Qr324 & & & & 17 & 100 & & 1 & 200 & \\
\hline
\end{tabular}


The occurrence of species which are protected was confirmed on almost all of the examined trees (Figure 6). Registered species composition is typical for valuable tree alleys in the area of Northeast Poland [92] and distinctive to the species described in other parts of the region [33-36,93]. Many species of epiphytic lichens are sensitive to air contamination, which particularly indicates the need to preserve matured and senescent trees as valuable habitats for protected species across the entire country.

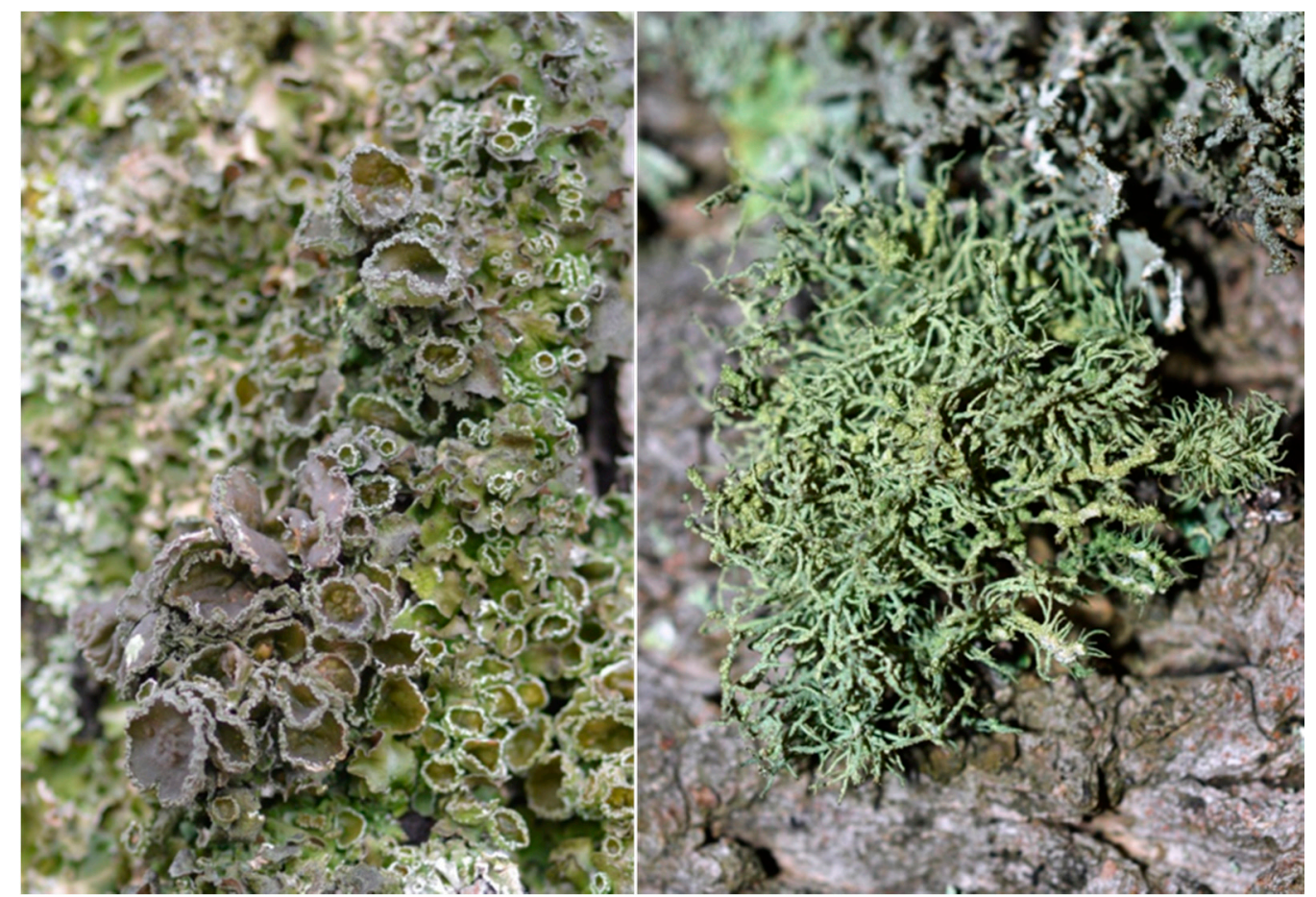

Figure 6. Example of protected lichen species under partial protection on the alley trees; Pleurosticta acetabulum (left), Usnea hirta (right).

Research has shown that the colonization and dispersion of propagule of some macro lichens, such as Evernia prunastri and Ramalina farinacea, occurred over distances of $30 \mathrm{~m}$ [94]. Therefore this distance between trees and groups of trees should be preserved during tree removal, replacing removed trees in order to maintain the possibility of spreading the lichen population [36].

\subsection{Examination of Bat Fauna}

At least nine bat species out of the 26 existing in Poland were recorded on the road alley. Unidentified species were present in the study area as well. All of the detected identified species are under species protection, and three of them are on the red list of extinct and threatened animals in Poland [95] (Table 4). As a result of the survey, the occurrence of potential hiding places within most of the trees along the road alley on the section of Wilimowo-Gamerki Wielkie was verified. The survey indicates that the Gamerki Wielkie-Jonkowo section is an especially valuable place for the local bat population. Detectors along the alley confirmed the existence of nine species of bats. In the analyzed period, Pipistrellus sp. dominated the chiropterofauna of the alley and its surrundings, constituting almost $50 \%$ of all the recorded fly-overs. A significant number of fly-overs belonged also to Nyctalus noctula (21\%), Eptesicus serotinus (13\%), and other unidentified bat species (Myotis sp.) (Figure 7). 
Table 4. Species of bats observed in the studied area. NT-near threatened; LC-least concern; VU-vulnerable.

\begin{tabular}{clc}
\hline Scientific Name & Status of Protection & $\begin{array}{c}\text { Status on the Red List of Extinct } \\
\text { and Threatened Animals }\end{array}$ \\
\hline Pipistrellus nathusii & strict protection & \\
Pipistrellus pipistrellus & strict protection & \\
Pipistrellus pygmaeus & strict protection & \\
Eptesicus serotinus & strict protection & $\mathrm{NT}$ \\
Eptesicus nilssonii & strict protection & $\mathrm{LC}$ \\
Vespertilio murinus & strict protection & $\mathrm{VU}$ \\
Nyctalus noctula & strict protection & \\
Nyctalus leisleri & strict protection & \\
Plecotus auritus & strict protection & \\
\hline
\end{tabular}

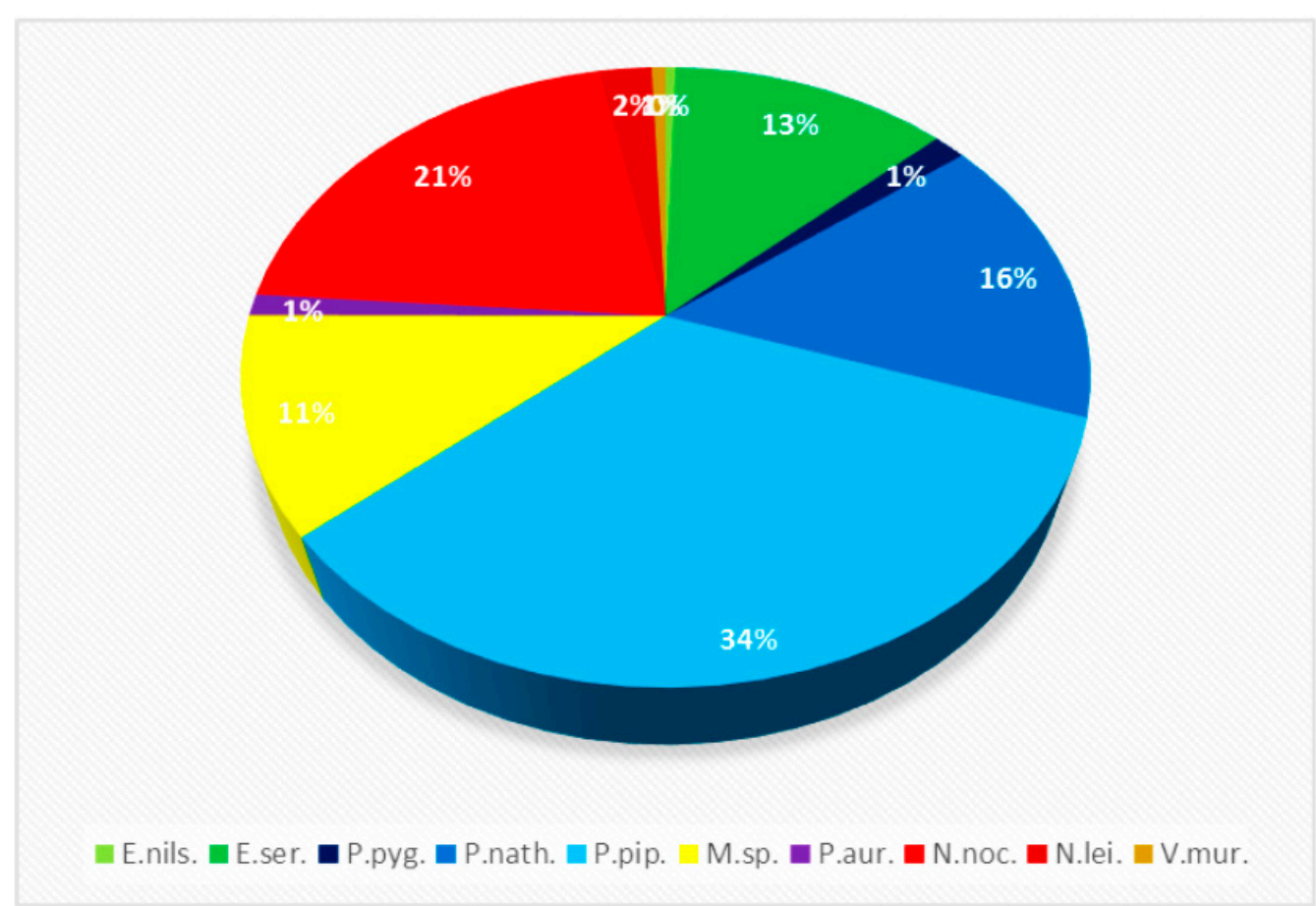

Figure 7. Species composition of the chiropterofauna of the analyzed avenue during the dispersion of breeding colonies at the beginning of autumn migration. E.nils.-Eptesicus serotinus, E.ser. —Eptesicus nilssonii, P.pyg._-Pipistrellus pygmaeus, P.nath._Pipistrellus nathusii, P.pip. —Pipistrellus pygmaeus, M.sp.-Myotis sp., P.aur.-Plecotus auritus, N.noc.-Nyctalus noctula, N.leis.-Nyctalus leisleri, V.mur.-Vespertilio murinus.

A number of feeding buzzes were recorded in 13 sections of the alley. Parts of the alley, in which the signals were recorded (Table 5), should therefore be valued as significant bat feeding places. Moreover, social sounds of Pipistrellus sp. were recorded in seven sections of the alley. The sounds are made by territorial males during breeding seasons. This proves that these sections of the alley are particularly important for bat reproduction. 
Table 5. The chiropterofauna-characteristics of the avenue sections.

\begin{tabular}{|c|c|c|c|c|}
\hline $\begin{array}{l}\text { Number of the } \\
\text { Road Section }\end{array}$ & Description of the Section & $\begin{array}{c}\text { Bats } \\
\text { Activity }\end{array}$ & $\begin{array}{l}\text { Feeding } \\
\text { Sounds }\end{array}$ & $\begin{array}{l}\text { Social } \\
\text { Sounds }\end{array}$ \\
\hline 1 & Bridge on Pasłęka river-Gamerki Wielkie & very high & $x$ & $X$ \\
\hline 3 & Gamerki Wielkie-edge of the forest & low & $x$ & \\
\hline 4 & Forest next to the Gamerskie Lake & high & $x$ & \\
\hline 5 & Gamerki Małe & low & & \\
\hline 8 & Alley till Kolonia Stare Kawkowo & low & $x$ & \\
\hline 9 & Kolonia Stare Kawkowo & low & & $X$ \\
\hline 10 & Kolonia Stare Kawkowo-Stare Kawkowo & moderate & & \\
\hline 11 & Stare Kawkowo & low & & \\
\hline 12 & Stare Kawkowo-Nowe Kawkowo & high & & \\
\hline 17 & power line-Pupki & low & & \\
\hline 18 & Pupki & low & $X$ & \\
\hline 19 & wetlands & low & & \\
\hline 20 & wetlands-edge of the forest & moderate & & $X$ \\
\hline 21 & Edge of the forest-road to Wegajty & moderate & $x$ & $X$ \\
\hline 22 & road to Węgajty-Ostoja Warmińskie Buczyny & moderate & & $X$ \\
\hline 23 & Ostoja Warmińskie Buczyny_-Jonkowo & high & $X$ & \\
\hline 24 & Kolonia Jonkowo & high & & \\
\hline 25 & Kolonia Jonkowo-cementary & moderate & $x$ & $x$ \\
\hline 26 & Jonkowo-build section & low & & \\
\hline 27 & Jonkowo dispersed housing & low & & \\
\hline
\end{tabular}

\subsection{Inventory of Hermit Beetle}

There were confirmed habitats and specimens of the protected hermit beetle species Osmoderma barnabita. Within the cavities of the trees observed, the occurrence of the hermit beetle's imago, along with a large amount of the species excrements were documented. Their habitat was also confirmed in two trees. There is a possibility of settlements in further trees in addition to the trees examined (Figure 8). The hermit beetle prefers hollow trees with trunk circumferences larger than $70 \mathrm{~cm}$ [96]. The existence of these trees within a $2000 \mathrm{~m}$ radius from each other is required to maintain the continuity of habitat in the trees. 


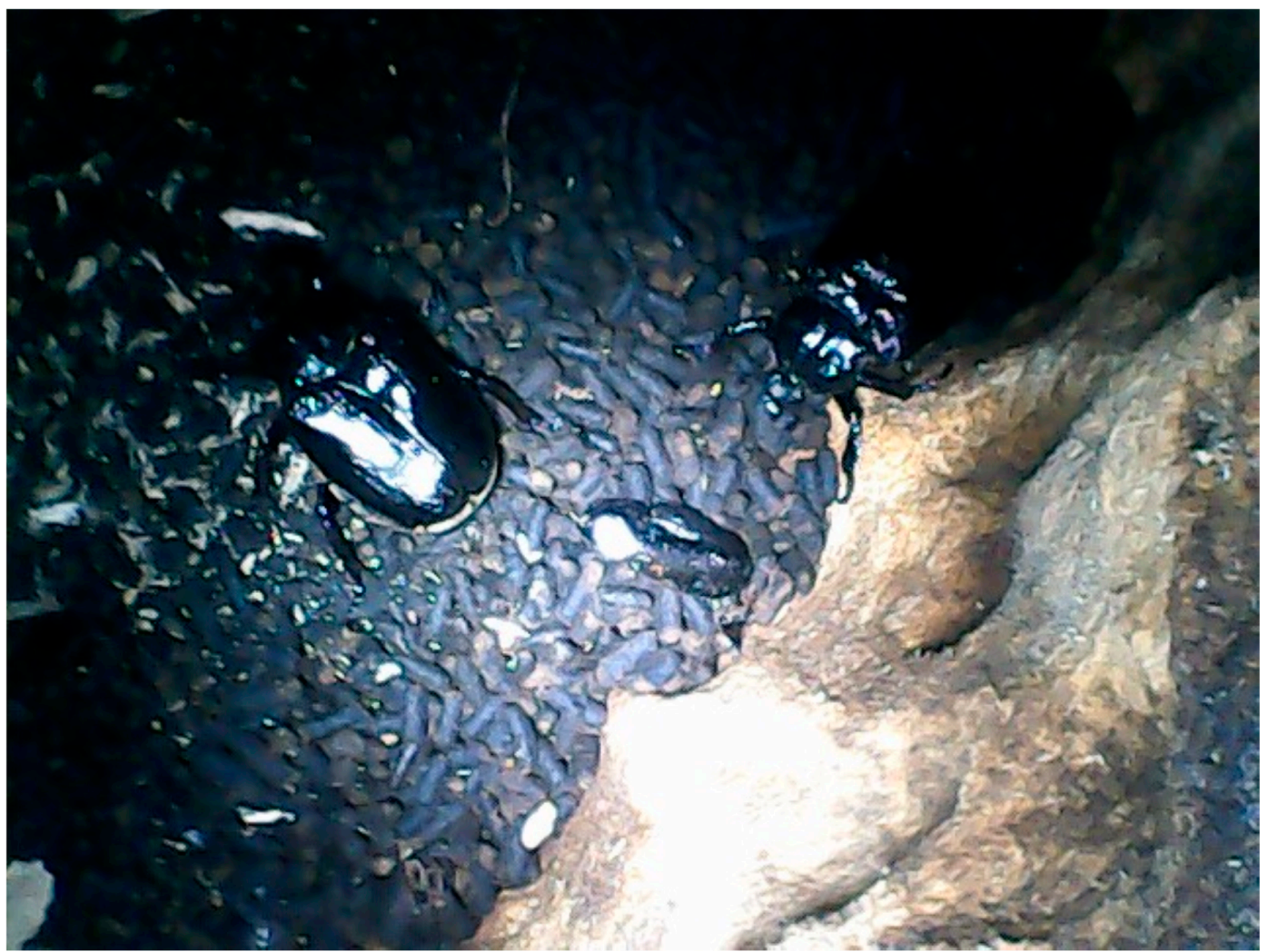

Figure 8. Hermit-beetles in one of the alley trees (view from endoscope camera).

Large trunk circumferences, many hollows, a small distance between trees and the occurrence of hermit beetle habitats within a few kilometers from each other proved the fact that the examined alley is an optimal habitat for the hermit beetle. The existence of active habitats of this species indicates good habitat preconditions [97]. Therefore, the hermit beetle is an indicator species on the list in attachment II of the "Habitats Directive". The places of occurrence of this species are potential locations for Nature 2000 protection.

\subsection{Final Evaluation of the Alley}

The safety evaluation revealed that only one tree out of twenty eight must be removed for safety reasons. The vitality class of tree No. 17, according to Roloff scale, was rated as 3-the oak was not safe for road users. An intense deadwood was visible in the crown. At the crown collar, at a height of $5 \mathrm{~m}$, the presence of a double-sided crack was found. The tree was qualified to the CD class (high risk of failure). It was possible to lower the risk level by pruning the tree crown (a reduction of $2 \mathrm{~m}$ ), removing the dried branches, tying the codominant trunks and providing annual monitoring. Another solution was to leave the trunk cut at a height of $3 \mathrm{~m}$ to save the protected species of lichens. However, due to a poor prognosis negating a long and safe life, as well as limited funds for monitoring and safety measures, the tree was selected for removal (Table 1).

The ecological-environmental evaluation confirmed the presence of the following protected species: nine bat species (three of them placed on a red list), with $50 \%$ fly-overs from Pipistrellus sp. and 13\% fly-overs from nearly threatened Eptericus serotinus; 2837 specimens of epiphytic lichens of nine different protected species (five species are placed on a red list of extinct or threatened lichens in Poland); the hermit beetle as an indicator species of the "Habitats Directive" (as it was written, presence of the species may be a reason for constitution of the form of nature protection (Natura 2000).

The final environmental valuation indicated that 27 trees are not a threat for traffic (unless treatment is implemented) and cannot be felled as being habitats for species protected by law. 


\section{Discussion}

The results confirmed those achieved in the study by Kanea [62]: trees with decayed stems and branches pose a low or moderate risk of failure, and only some parts of them demand safety treatments.

Within the examined group, only one tree (No. 17) was found to be dangerous for road users' safety and indicated for removal, partly because of the extended dead wood presence in a crown, but especially because of a double sided crack in the crown collar. The loss of only one tree allowed the habitat and landscape value of the avenue to be maintained. In the instances of other trees, there were proposed treatments to improve their stability and safety. The risk level was minimized by the implementation of treatments recommended by experts as a result of tree diagnostic investigation in our study. Dry branches were removed from the crowns of 11 trees. Eight trees were protected by elastic ties. Parts of trunks or branches which could cause traffic threats were marked by fluorescent bands. All the safety treatment effects were noticeable for dwellers and travelers. This in turn allowed for the spread of knowledge about safety improvement methods around the trees and tree benefit education for a public like improvement of safety on roads $[61,97,98]$.

Trees, which were indicated for removal by the road supervisor, were checked and the risk was minimized to the accepted level. All the planned actions regarding the avenue were projected according to not worsen the actual condition of the protected species habitat. The basic assumption considers the number of trees, which are potential habitats for hermit beetle, should not be reduced. Moreover, in the case of the examined alley, it is necessary to plant new trees in the empty sections between mature trees in order to improve the future migration capacity between existing and potential habitats. Alleys are a key component able to enhance connectivity and facilitate the movement of organisms between green patches such as woodland, forest or urban green infrastructure [98]. Tree maintenance can consider the evaluation of tree condition and risk estimation; this in turn will enable the preservation of the landscape value and improve the whole natural system function. It should be emphasized that the typical approach, assuming that mature trees can be felled and replaced with seedlings of young trees, does not show the loss of biodiversity and ecosystems, which cannot be compared to the small contribution of recently created habitats connected with new plantings $[99,100]$. Ecosystem services provided by trees are dependent on tree size and biomass [101,102]. For example, trunk diameter is positively related to the presence of decay-cavities. Tree-cavities are generally an important ecological factor as a number of animals living in woody habitats are cavity users, and in the case of our study, that kind of tree has been selected for removal. What's worth mentioning is that the decay-cavities occur as a result of the removal of large branches. Decay-cavities are featured more often in trees of low vitality and with woodpecker-cavities than in trees of high vitality or without woodpecker-cavities [102]. From another site, the presence of saproxylic beetles in the cavities is positively associated with tree height and the high degree of damage at the root collar, which could be a factor increasing the risk level, and negatively associated with the presence of hole-nesting birds [70]. In the case of necessity to eliminate a tree that creates a risk, constituting at the same time a habitat of protected species (especially lichens and beetles colonizing the cavities), a certain compromise may be cutting the tree at a height of several meters and leaving the bottom part of the trunk. Although it should be remembered that such a solution will not be fully effective due to the change of the temperature and humidity conditions within the trunk, which may be exposed to over drying and flooding.

The protection of rare species, e.g., lichens, provides ecosystem services and is strictly connected to the protection of mature and old trees, as studied. For example, microlichens which are particularly sensitive to air pollution, also from the genera Ramalina and Usnea [103], which were recognized in the study. The large presence of mentioned microlichens confirms that the study area is characterized by good air quality, which is uncommon in Poland-a country with high $\mathrm{CO}_{2}$ emissions.

Coniferous trees dominate forests in the Warmia and Mazury regions. Broad leaf trees in the forests rarely reach a large size due to forestry practices, thus many species do not have proper conditions in such modified forests. Therefore, alleys provide suitable habitats and are often the 
main habitat for epiphytic lichens, which is related to the large size of broad leaf trees preferred by most of the macro epiphytic protected lichens. This has also been confirmed by preliminary studies, which were conducted in some tree avenues in the regions of Warmia, Mazury and the Wysoczyzna Elblaska and revealed the presence of more than 120 lichen species, including 22 that were red listed $[32,34,36]$. The threat from global climate change on lichens and a lack of proper habitats in forests particularly indicates the need to preserve mature and senescent trees as valuable habitats of protected species across the entire country. A similar situation concerns the hermit bettle. Due to a lack of large, hollow, deciduous trees in managed forest in the Warmia region [104], a majority of the population occupies tress in alleys [91]. This species has very limited migratory possibilities [96,97,105], therefore the presence of a possibly dense alley network with mature, hollow trees is crucial to counteract the isolation of subpopulations of the hermit beetle, and to ensure connectivity between separated populations.

The rich diversity of bat species and numerous registered signs of their existence showed the immense significance of the examined alley for the local bat population. Due to the use of road trees by some of the bats as ecological corridors during migration [29], retaining the spatial continuity of road trees constitutes a significant criterion for alley management.

The survey results indicated the necessity of special protection for the old tree alley. The use of tree risk assessment methods prevents the unjustified felling of trees and maintains the legally required low level of risk. However, some studies show clearly that protected species are at risk of removal from the urban environment due to a clash of interests between biodiversity conservation and public safety assessed on the basis of Visual Tree Assessment Procedure (VTA) [106]. This indicates the necessity of implementation for risk management that takes into consideration both of the priorities. The alley has unique habitat and landscape values, and maintaining these values will support biodiversity and increase touristic potential and educational function. There are fewer and fewer rich ecosystems like this one, that function in the rural and urban areas. The existence of the alley is a big advantage for the region and its preservation will bring ecological and economical profits to the local government and inhabitants by touristic popularization. This indicates a justified need for reconstructing old alleys and creating new ones. This study has only partially revealed some of the multifunctional benefits of alleys within an area. Alleys and trees in general, allow a green ecosystem to exist within an urbanized area. These ecosystems in turn allow for the environmental protection that leads to economic development, as well as an increase in social health and equality. The correct management of road trees needs to be pushed to the forefront of planning to help promote sustainability targets $[1,4,107]$.

Other research has confirmed the decreasing number of deciduous trees containing hollows, and points to the increasing consumer demand for forested wood products from trees over 100 years old as a cause. This increases the importance of protecting groups of deciduous trees, many of which occur along roadsides. Proactive management, appropriate planning, implementation and resourcing are key elements in ensuring that the benefits of green environments can be optimized. However, studies show that the majority of local municipalities are not managing the urban trees and green spaces systematically, owing to constraints such as insufficient funds, insufficient personnel, lack of equipment and the absence of political interest [108].

The results confirmed the necessity to evaluate alleys taking into consideration both "flora and fauna". In Poland, it is still a common practice to examine trees only referring to their vitality. Such an approach seems to be insufficient, especially when a tree is a part of a bigger structure like an alley. Therefore, certain standards should be set for their evaluation, including accurate methods adjusted to the landscape and habitat type, as well as to their surroundings.

\section{Conclusions}

This study presents a novel approach to assessing the environmental value of road alleys, connecting safety with ecological and environmental aspects in order to ensure the sustainability of the region. The six-component examination framework for the research-dendrological examination 
with tree risk assessment and vitality evaluation, loading tests, examination of protected beetle species-hermit beetle, the lichens species, and examination of bat fauna-guided an approach with complementary measures that shows the environmental value of the examined road alley. The study demonstrates that the responsible assessment of the avenue requires a consideration of all these important factors. Therefore, alleys cannot be perceived only as a part of the road system, in which they cause threats for road users, especially since professional risk assessment has not confirmed the need for tree removal. In this case, it was possible to reduce the level of risk by providing safety recommendations. For these reasons, an expanded resource management plan should become a common practice. This approach has become increasingly important, as dendrologists continue to highlight the utilitarian relationship residents have with local alleys, described in some case even as a "mental space", and the apprehensions they have about these spaces $[1,7,28]$. Further studies should be made in order to implement full procedures (risk and natural value assessment) into decision making processes concerning road management. Taking into account the wide range of urban alleyways' value and meaning, our study indicates viable ways to direct management system creation based on two priorities: safety and biodiversity protection.

Supplementary Materials: The following are available online at http:/ /www.mdpi.com/2071-1050/11/6/1816/ s1, Figure S1: Main species of trees in the alley.

Author Contributions: Conceptualization, M.S.; methodology, M.S.; software, M.S. and M.B.; validation, M.S. and M.B.; formal analysis, M.S., A.J., J.D., A.B. and J.S.; resources, M.S., M.B., A.J., J.D., A.B. and J.S.; data curation, M.S. and M.B.; writing — original draft preparation, M.S. and M.B.; writing - review and editing, M.S. and M.B.; project administration, M.B.

Funding: This research was carried in cooperation with Stowarzyszenie Ekologiczno-Artystyczne "Rẹka Dzieło" (representing Fundacja Ekologiczna Arka in the "DZIAŁAJ w ZIELONE-Program inicjatyw lokalnych" project) and was funded by Narodowy Fundusz ochrony Środowiska i Gospodarki Wodnej (ang. National Fund for Environmental Protection and Water Management).

Acknowledgments: We would like to thank Gabriela Maksymiuk, $\mathrm{PhD}$, for her valuable comments and methodological support while preparing this paper.

Conflicts of Interest: The authors declare no conflict of interest.

\section{References}

1. Newell, J.P.; Seymour, M.; Yee, T.; Renteria, J.; Longcore, T.; Wolch, J.R.; Shishkovsky, R.A. Green Alley Programs: Planning for a sustainable urban infrastructure? Cities 2013, 31, 144-155. [CrossRef]

2. Lo, A.Y.H.; Jim, C.Y. Differential community effects on perception and use of urban greenspaces. Cities 2010, 27, 430-442. [CrossRef]

3. Martin, M.D. The question of alleys, revisited. Urban Des. Int. 2001, 6, 76-92. [CrossRef]

4. Giedych, R.; Maksymiuk, G. Specific Features of Parks and Their Impact on Regulation and Cultural Ecosystem Services Provision in Warsaw, Poland. Sustainability 2017, 9, 792. [CrossRef]

5. Hasan, R.; Othman, N.; Faridah, I. Roadside Tree Management in Selected Local Authorities for Public Safety. Procedia Soc. Behav. Sci. 2016, 234, 218-227. [CrossRef]

6. Ford, L.R. Alleys and urban form: Testing the tenets of new urbanism. Urban Geogr. 2001, 22, 268-287. [CrossRef]

7. Suchocka, M.; Jankowski, P.; Błaszczyk, M. Perception of Urban Trees by Polish Tree Professionals vs. Nonprofessionals. Sustainability 2019, 11, 211. [CrossRef]

8. Richling, A.; Solon, J. Ekologia Krajobrazu; Wydawnictwo Naukowe PWN: Warszawa, Poland, 1998; p. 132.

9. Akbar, K.F.; Hale, W.H.G.; Headley, A.D. Assessment of scenic beauty of the roadside vegetation in northern England. Landsc. Urban Plan. 2003, 63, 139-144. [CrossRef]

10. Stamatiadis, N.; Bailey, K.; Grossardt, T. Evaluation of highway design parameters on influencing operator speeds through casewise visual evaluation. Transp. Res. Rec. J. Transp. Res. Board 2010, 2195, 143-149. [CrossRef] 
11. Naderi, J.R.; Kweon, B.S.; Maghelal, P. Simulating impacts of curb-side trees on driver performance and perceptions. In Proceedings of the 85th Annual Meeting Transportation Research Board, Washington, DC, USA, 22-26 January 2006.

12. Huang, B.K. Dynamic simulation of a vehicle interacting with biological and physical systems. In Proceedings of the IEEE American Control Conference, Minneapolis, MN, USA, 10-12 June 1987.

13. Przesmycka, E. Aleja jako wyznacznik stanu zachowania tożsamości europejskiego krajobrazu kulturowego na przykładzie Polski południowo-wschodniej [Alley as a determinant of the European cultural landscape identity on the example of south-eastern Poland]. Architektura Krajobrazu 2011, 1, 44-53. (In Polish)

14. Liżewska, I.; Zwierowicz, M. Aleje przydrożne-Dziedzictwo historyczne, stan zachowania, ochrona. In Aleje Przydrożne. Historia, Znaczenie, Zagrożenie, Ochrona; Worobiec, K.A., Liżewska, I., Eds.; Borussia: Olsztyn, Poland, 2009; pp. 95-112.

15. O'Sullivan, O.S.; Holt, A.R.; Warren, P.H.; Evans, K.L. Optimizing UK urban road verge contributions to biodiversity and ecosystem services with cost-effective management. J. Environ. Manag. 2017, 191, 162-171. [CrossRef] [PubMed]

16. Stojnić, S.; Suchocka, M.; Benito-Garzón, M.; Torres-Ruiz, J.M.; Cochard, H.; Bolte, A.; Cocozza, C.; Cvjetković, B.; De Luis, M.; Martinez-Vilalta, J.; et al. Variation in xylem vulnerability to embolism in European beech from geographically marginal populations. Tree Physiol. 2017, 1-13. [CrossRef]

17. Bennett, A.F. Linkages in the Landscape: The Role of Corridors and Connectivity in Wildlife Conservation; International Union for Conservation of Nature and Natural Resources: Cambridge, UK, 1999.

18. Vergnes, A.; Le Viol, I.; Clergeau, P. Green corridors in urban landscapes affect the arthropod communities of domestic gardens. Biol. Conserv. 2012, 145, 171-178. [CrossRef]

19. Fahrig, L. Effects of habitat fragmentation on biodiversity. Annu. Rev. Ecol. Evol. Syst. 2003, 34, 487-515. [CrossRef]

20. Kong, F.; Yin, H.; Nakagoshi, N.; Zong, Y. Urban green space network development for biodiversity conservation: Identification based on graph theory and gravity modeling. Landsc. Urban Plan. 2010, 95, 16-27. [CrossRef]

21. Tian, Y.; Jim, C.Y.; Tao, Y.; Shi, T. Landscape ecological assessment of green space fragmentation in Hong Kong. Urban For. Urban Green. 2011, 10, 79-86. [CrossRef]

22. Randolph, J. Environmental Land Use and Management; Island Press: Washington, DC, USA, 2003.

23. Mckinney, M.L. Urbanization, Biodiversity, and Conservation. Bioscience 2002, 52, 883-890. [CrossRef]

24. Draus, P.; Lovall, S.; Formby, T.; Baldwin, L.; Lowe-anderson, W.; Lovall, S.; Baldwin, L.; Lowe-anderson, W. A Green Space Vision in Southeast Michigan's Most Heavily Industrialized Area. Urban Ecosyst. 2018, 22, 91-102. [CrossRef]

25. Bolund, P.; Hunhammar, S. Ecosystem services in urban areas. Ecol. Econ. 1999, 29, 293-301. [CrossRef]

26. Hunter, M.R.; Askarinejad, A. Designer's approach for scene selection in tests of preference and restoration along a continuum of natural to manmade environments. Front. Psychol. 2015, 6, 1-21. [CrossRef] [PubMed]

27. Oleksa, A.; Kadej, M.; Smolis, A. Chronione owady [Protected insects]. In Aleje skarbnice przyrody. Praktyczny Podręcznik Ochrony Alej i Ich Mieszkańców; Tyszko-Chmielowiec, P., Ed.; Fundacja EkoRozwoju: Wrocław, Poland, 2012; pp. 53-80. (In Polish)

28. Orłowska, B. Ptaki [The Birds]. In Aleje Skarbnice Przyrody. Praktyczny Podręcznik Ochrony Alej i Ich Mieszkańców; Tyszko-Chmielowiec, P., Ed.; Fundacja EkoRozwoju: Wrocław, Poland, 2012; pp. 81-92. (In Polish)

29. Furmankiewicz, J. Nietoperze [The Bats]. In Aleje Skarbnice Przyrody. Praktyczny Podręcznik Ochrony Alej $i$ Ich Mieszkańców; Tyszko-Chmielowiec, P., Ed.; Fundacja EkoRozwoju: Wrocław, Poland, 2012; pp. 93-102. (In Polish)

30. Kadej, M.; Smolis, A. Przyrodnicza waloryzacja drzew-Określanie przyrodniczej wartości drzewa, w tym rozpoznanie gatunków chronionych, zgodnie z wymaganiami ustawy o ochronie przyrody. In Drzewa w Krajobrazie; FER: Wrocław, Poland, 2015. (In Polish)

31. Jurczyszyn, M. Popielicowate [The Dormouse]. In Aleje Skarbnice Przyrody Praktyczny Podręcznik Ochrony Alej i Ich Mieszkańców; Tyszko-Chmielowiec, P., Ed.; Fundacja EkoRozwoju: Wrocław, Poland, 2012; pp. 103-106. (In Polish) 
32. Cieśliński, S. Atlas rozmieszczenia porostów (Lichenes) w Polsce Północno-Wschodniej [Atlas of lichen distribution (Lichenes) in North-Eastern Poland]. Phytocoenosis-Supplementum Cartographiae Geobotanicae 2003, 15, 1-426. (In Polish)

33. Gruszka, W. The protected and threatened lichens of roadside trees in the Krajeńskie Lakeland. In Lichen Protection—Protected Lichen Species; Lipnicki, L., Ed.; Sonar Literacki, Gorzów Wlkp.: Gorzów, Poland, 2012; pp. 277-286.

34. Szymczyk, R.; Zalewska, A.; Szydłowska, J. Protection of lichen species along roadside tree rows in the region of Warmia and Mazury. In Lichen Protection—Protected Lichen Species; Lipnicki, L., Ed.; Sonar Literacki, Gorzów Wlkp.: Gorzów, Poland, 2012; pp. 337-338.

35. Szymczyk, R.; Kowalewska, A. Inwentaryzacja Porostów Epifitycznych Wybranych Zadrzewień Przydrożnych Województwa Pomorskiego ze Szczególnym Uwzględnieniem Gatunków Chronionych; Manuscript; Regionalna Dyrekcja Ochrony Środowiska w Gdańsku: Gdańsk, Poland, 2015.

36. Szymczyk, R.; Zalewska, A. Does roadside tree maintenance affects occurrences of protected lichen species? In Proceedings of the XX Symposium of Baltic Mycologists and Lichenologists, Gdańsk, Poland, 25-29 September 2017; pp. 28-36.

37. Rose, F. Lichenological indicators of age and environmental continuity in woodlands. In Lichenology: Progress and Problems; Brown, D.H., Ed.; Academic Press: London, UK, 1976; pp. 279-307.

38. Sett, R.; Kundu, M. Epiphytic Lichens: Their Usefulness as Bio-indicators of Air Pollution Donnish. J. Res. Environ. Stud. 2016, 3, 17-24.

39. Stubbs, C.S. Patterns of Distribution and Abundance of Corticolous Lichens and Their Invertebrate Associates on Quercus rubra in Maine. Bryologist 1989, 92, 453-460.

40. Gerson, U. Lichen-Arthropod Associations. Lichenologist 1973, 5, 434-443. [CrossRef]

41. Asplund, J.; Wardle, D. How lichens impact on terrestrial community and ecosystem properties. Biol. Rev. 2017, 92, 1720-1738. [CrossRef] [PubMed]

42. Bobbink, R.; Hicks, K.; Galloway, J.; Spranger, T.; Alkemade, R.; Ashmore, M.; Bustamante, M.; Cinderby, S.; Davidson, E.; Dentener, F.; et al. Global assessment of nitrogen deposition effects on terrestrial plant diversity: A synthesis. Ecol. Appl. 2010, 30-59. [CrossRef]

43. Bishop, O.J. A Multi-scale Exploration into the Spatial Patterns of a Three Dimensional Urban Tree Infrastructure (UTI): Integrating Landscape Connectivity, Network Resilience, and Social Deprivation; University of Salford: Salford, UK, 2015.

44. Thompson, P.L.; Gonzalez, A. Dispersal governs the reorganization of ecological networks under environmental change. Nat. Ecol. Evol. 2017, 1, 0162. [CrossRef]

45. Vale, T.R.; Vale, G.R. Suburban bird populations in west-central California. J. Biogeogr. 1976, 3, $157-165$. [CrossRef]

46. Czech, B.; Krausman, P.R.; Devers, P.K. Economic associations among causes of species endangerment in the United States. BioScience 2000, 50, 593-601. [CrossRef]

47. Imai, H. The liminal nature of alleyways: Understanding the alleyway roji as a 'Boundary' between past and present. Cities 2013, 34, 58-66. [CrossRef]

48. Seymour, M.; Wolch, J.; Reynolds, K.D.; Bradbury, H. Resident perceptions of urban alleys and urban alley greening. Appl. Geogr. 2010, 30, 380-393. [CrossRef]

49. Worobiec, K. Ochrona alei w krajach sasiednich-Na przykładzie Meklemburgii i Brandenburgii [Protection of avenues in neighboring countries-On the example of Mecklenburg and Brandenburg]. In Aleje Przydrożne. Historia, Znaczenie, Zagrożenie, Ochrona; Worobiec, K.A., Liżewska, I., Eds.; Borussia: Olsztyn, Poland, 2009; pp. 213-228. (In Polish)

50. Schäffler, A.; Swilling, M. Valuing green infrastructure in an urban environment under pressure. The Johannesburg case. Ecol. Econ. 2013, 86, 246-257. [CrossRef]

51. Kabisch, N.; Strohbach, M.; Haase, D.; Kronenberg, J. Urban green space availability in European cities. Ecol. Indic. 2016, 70, 586-596. [CrossRef]

52. Szulczewska, B.; Giedych, R.; Maksymiuk, G. Can we face the challenge: How to implement a theoretical concept of green infrastructure into planning practice? Warsaw case study. Landsc. Res. 2017, 42, 176-194. [CrossRef]

53. Koeser, A.K.; Klein, R.W.; Hasing, G.; Northrop, R.J. Factors driving professional and public urban tree risk perception. Urban For. Urban Green. 2015, 14, 968-974. [CrossRef] 
54. Mell, I.C.; Henneberry, J.; Hehl-Lange, S.; Keskin, B. Promoting urban greening: Valuing the development of green infrastructure investments in the urban core of Manchester, UK. Urban For. Urban Green. 2013, 12, 296-306. [CrossRef]

55. Van der Horst, R.; De Ridder, S. Influence of roadside infrastructure on driving behavior: Driving simulator study. In Transportation Research Record: Journal of the Transportation Research Board; TRB of the National Academies: Washington, DC, USA, 2007. [CrossRef]

56. Worobiec, K.A. Drzewa przydrożne w krajobrazie-Historia, korzyści dla przyrody i społeczeństwa. In Jak dbać o drzewa. Dobre praktyki ochrony zadrzewień; Zientek-Varda, J., Ed.; Fundacja EkoRozwoju: Wrocław, Poland, 2013; pp. 9-24, ISBN 978-83-63573-05-8.

57. Worobiec, K.A.; Liżewska, I. Stowarzyszenie na Rzecz Ochrony Krajobrazu Kulturowego Mazur "Sadyba", Kadzidłowo-Olszyn. In Aleje przydrożne. Historia, znaczenie, zagrożenie, ochrona; Borussia: Olsztyn, Poland, 2009; p. 178. ISBN 978-83-89233-51-6.

58. Mattila, O.L.; Häyrinen, T.M.; Toppinen, A.; Berghäll, S. Challenges of municipal greening and multifunctional forest management: The case of Finland. Urban For. Urban Green. 2015, 14, 982-990. [CrossRef]

59. Stamatiadis, N.; Bailey, K.; Grossardt, T.; Ripy, J.; Strombotne, A. Use of context sensitive methods to influence operating speeds: Case study of rural highway by casewise visual evaluation. Transp. Res. Rec. J. Transp. Res. Board 2007, 2025, 90-97. [CrossRef]

60. Borowski, J. Zasady prawidłowej pielegnacji drzew. Jak można uniknąć wycinania starych alej przydrożnych? [Principles of proper tree care. How can you avoid cutting old roadside avenues?]. In Aleje Podręcznik Użytkownika. Jak Dbać o Drzewa, Aby Nam Stużyły; Tyszko-Chmielowiec, P., Witkoś, K., Eds.; Drogi dla Natury: Wrocław, Poland, 2012; p. 45. (In Polish)

61. Suchocka, M.; Niewiarowska, A. Wpływ ekosystemów odcinków dróg na bezpieczeństwo ruchu drogowego [Impact of road ecosystems on road safety]. Drogownictwo 2016, 6, 200-206. (In Polish)

62. Kanea, B.; Warrena, P.S.; Lermanab, S.B. A broad scale analysis of tree risk, mitigation and potential habitat for cavity-nesting birds. Urban For. Urban Green. 2015, 14, 1137-1146. [CrossRef]

63. Paine, L.A. Accident Hazard Evaluation and Control Decisions on Forested Recreation Sites; USDA Forest Service Research Paper PSW 68; Pacific Southwest Forest and Range Experiment Station: Berkeley, CA, USA, 1971; p. 10.

64. Helliwell, D.R. Acceptable level of risk associated with trees. Arboric. J. 1990, 14, 159162. [CrossRef]

65. Matheny, N.P.; Clark, J.R. A Photographic Guide to the Evaluation of Hazard Trees in Urban Areas, 2nd ed.; International Society of Arboriculture: Champaign, IL, USA, 1994; 85p.

66. Ellison, M.J. Quantified Tree Risk Assessment Used in The Management of Amenity Trees. J. Arboricult. 2005, 31, 57-65.

67. Mattheck, C.; Breloer, H. The Body Language of Trees; HMSO: London, UK, 1994; p. 241.

68. FLL. Baumkontrollrichtlinien, Richtlinien für regelkontrollen zur Überprüfung der Verkehrssicherheit von Bäumen; Forschungsgesellschaft Landschaftsentwicklung Landschaftsbau e.V.: Bonn, Germany, 2010; p. 30.

69. Baumgarten, H.; Doobe, G.; Dujesiefken, D.; Jaskula, P.; Kowol, T.; Wohlers, A. Kommunale Baumkontrolle zur Verkehrssicherheit; Haymarket Media: Braunschweig, Germany, 2010; p. 56.

70. Chiu, H.Y.; Chau, K.C. Best Practices for Urban Tree Management Begin with Sound Institutional Support and Legislation. Department of Geography \& Resource Management, CUHK, 2010. Available online: http:/ / www2.cuhk.edu.hk/GreenEducation/portals/0/content/treeseminar/2010/2010-02.pdf (accessed on 25 March 2019).

71. Radzikowski, T. Wypadki z drzewami skala problem-Charakterystyka. In Poprawa bezpieczeństwa ruchu na drogach obsadzonych drzewami, Proceedings of the Conference Wizja zero dla polskich alej., Otrębusy, Poland, 3-4 December 2015; pp. 16-24.

72. Poprawa bezpieczeństwa w ruchu drogowym. Available online: http://zachodniopomorska.policja.gov.pl/ sz/aktualnosci/projekty-realizowa/wspolpra/inte/17832,INT-45-Poprawa-Bezpieczenstwa-w-ruchudrogowym.html?search=93699295288787 (accessed on 11 September 2018).

73. Naderi, J.R.; Kweon, B.; Maghelal, P. The Street tree Effect and Driver Safety, ITE Journal on the Web. 2008. Available online: http://www.naturewithin.info/Roadside/Tree\&Driver_ITE.pdfdostęp (accessed on 9 April 2016). 
74. Rosenblatt Naderi, J. Landscape design in the clear zone: Effect of landscape variables on pedestrian health and driver safety. Transp. Res. Rec. 2003, 1851, 119-130. [CrossRef]

75. Drottenborg, H. Are Beautiful Traffic Environments Safer Than Ugly Traffic Environments? Ph.D. Thesis, Lund University, Lund, Sweden, 2002. Available online: http:/ / www.getcited.org/pub/103430785 (accessed on 14 January 2012).

76. Dumbaugh, E. Safe streets, livable streets. J. Am. Plan. Assoc. 2005, 71, 283-300. [CrossRef]

77. Mok, J.H.; Landphair, H.C.; Naderi, J.R. Landscape improvement impacts on roadside safety in Texas. Lands. Urban Plan. 2006, 78, 263-274. [CrossRef]

78. Parsons, R.; Tassinary, L.G.; Ulrich, R.S.; Hebl, M.R.; Grossman-Alexander, M. The view from the road: Implications for stress recovery and immunization. J. Environ. Psychol. 1998, 18, 113-139. [CrossRef]

79. Szczepanowska, H.B. Drzewa w otoczeniu ulic-Problemy inżynieryjne, społeczne, ekonomiczne oraz bezpieczeństwa [Street trees-Engineering, social, economic and safety aspects]. Człowiek i Środowisko 2008, 32, 87-107. (In Polish)

80. Topp, H.H. Traffic safety, usability and streetscape effects of new design principles for major urban roads. Transportation 1990, 16, 297-310. [CrossRef]

81. Cackowski, J.M.; Nasar, J.L. The restorative effects of roadside vegetation. Implications for automobile driver anger and frustration. Environ. Behav. 2003, 35, 736-751. [CrossRef]

82. Romanowski, P.; (Ecological-Artistic Society "Ręką Dzieło", Poland). Stowarzyszenie Ekologiczno-Artystyczne "Ręką Dzieło" Godki, Poland. Personal communication, 2019.

83. Dąbrowski, S.; Polakowski, B.; Wołos, L. Obszary Chronione i Pomniki Przyrody Województwa Warmińsko-Mazurskiego; Urząd Wojewódzki: Olsztyn, Poland, 1999; pp. 48-67.

84. Oleksa, A.; Kadej, M.; Smolis, A. Chronione owady. In Aleje skarbnice przyrody; Tyszko-Chmielowiec, P., Ed.; Fundacja EkoRozwoju: Wrocław, Poland, 2012; pp. 53-80, ISBN 978-83-63573-00-3.

85. Furmankiewicz, J. Nietoperze. In Aleje skarbnice przyrody; Tyszko-Chmielowiec, P., Ed.; Fundacja EkoRozwoju: Wrocław, Poland, 6357; pp. 93-102. ISBN 978-83-63573-00-3.

86. Smiley, E.T.; Kumamoto, H. Qualitative tree risk assessment. Arborist News 2012, 21, 12-18.

87. Mattheck, C. Trees: The Mechanical Design; Springer: Berlin/Heidelberg, Germany, 1991; p. 120.

88. Koeser, A.K.; Smiley, E.T. Impact of assessor on tree risk assessment ratings and prescribed mitigation measures. Urban For. Urban Green. 2017, 24, 109-115. [CrossRef]

89. Peltola, H.M. Mechanical stability of tree under static loads. Am. J. Bot. 2006, 93, 1501-1511. [CrossRef]

90. Roloff, A. Handbuch Baumdiagnostik Baum-Korpersprache und Baum-Beurtailung; Ulmer Verlag: Stuttgart, Germany, 2015.

91. Burchardt, L.; Łastowski, K.; Szmajda, P. Różnorodność ekologiczna, a bioindykacja. Teoria i praktyka badań ekologicznych. In Idee ekologiczne; Wydawnictwo Sorus: Poznań, Poland, 1994; Volume 4, pp. 27-43.

92. Cieśliński, S.; Czyżewska, K. Problemy agrożenia porostów w Polsce [Problems of lichen threat in Poland]. Wiadomości Botaniczne 1992, 36, 5-17. (In Polish)

93. Juźwiak, A. Lokalny Program Kształtowania Zadrzewień Przydrożnych Dla Gminy Gardeja; Program Drogi dla Natury: Kwidzyn, Poland, 2013. (In Polish)

94. Tapper, R. Dispersal and changes in local distributions of Evernia prunastri and Ramalina farinacea. New Phytol. 1976, 77, 725-734. [CrossRef]

95. Głowaciński, Z. (Ed.) Red List of Threatened Animals in Poland; Polish Academy of Sciences, Institute of Nature Conservation: Cracow, Poland, 2002; p. 156.

96. Oleksa, A. Ochrona Pachnicy w Polsce. Propozycja Programu Działań; [Protection of the hermit beetle in Poland. Proposed action program]; Fundacja EkoRozwoju: Wrocław, Poland, 2012. (In Polish)

97. Ranius, T. Osmoderma eremita as an indicator of species richness of beetles in tree hollows. Biodiv. Conserv. 2002, 11, 931-941. [CrossRef]

98. Zhang, Z.; Meerow, S.; Newell, J.; Lindquist, M. Enhancing Landscape Connectivity through Multi-functional Green Infrastructure Corridor Modeling and Design. Urban For.Urban Green. 2019, 38, 305-317. [CrossRef]

99. Escobedo, F.J.; Kroeger, T.; Wagner, J.E. Urban forests and pollution mitigation: Analyzing ecosystem services and disservices. Environ. Pollut. 2011, 159, 2078-2087. [CrossRef] [PubMed]

100. Bull, J.W.; Suttle, K.B.; Gordon, A.; Singh, N.J.; Milner-Gulland, E.J. Biodiversity offsets in theory and practice. Oryx 2013, 47, 369-380. [CrossRef] 
101. McPherson, E.G.; Nowak, D.; Heisler, G.; Grimmond, S.; Souch, C.; Grant, R.; Rowntree, R. Quantifying urban forest structure, function, and value: The Chicago urban forest climate project. Urban Ecosyst. 1997, 1, 49-61. [CrossRef]

102. Wolf, K.L. Roadside Urban Trees-Balancing safety and Community Values. Arborist News 2006, 15, $25-27$.

103. Blett, T.; Geiser, L.; Porter, E. Air Pollution-Related Lichen Monitoring in National Parks, Forests, and Refuges: Guidelines for Studies Intended for Regulatory and Management Purposes; National Park Service Air Resources Division: Portland, Oregon, 2003; pp. 235-260.

104. Czerepko, J. Stan Różnorodności Biologicznej Lasów w Polsce na Podstawie Powierzchni Obserwacyjnych Monitoring; Instytut Badawczy Leśnictwa: Sękocin, Poland, 2008; p. 168.

105. Hedin, J.; Ranius, T.; Nilsson, S.G.; Smith, H.G. Restricted dispersal in a flying beetle assessed by telemetry. Biodiv. Conserv. 2007, 17, 675-684. [CrossRef]

106. Carpaneto, G.M.; Mazziotta, A.; Coletti, G.; Audisio, P.; Luiselli, L. Conflict between insect conservation and public safety: The case study of a saproxylic beetle (Osmoderma eremita) in urban parks. J. Insect Conserv. 2010, 14, 555-565. [CrossRef]

107. Nowak, D.J.; Dwyer, J.F. Understanding the benefits and costs of urban forest ecosystems. In Urban and Community Forestry in the Northeast; Kuser, J., Ed.; Springer Science and Business Media: New York, NY, USA, 2007; p. 235.

108. Chishaleshalea, M.; Shackletona, C.M.; Gambizaa, J.; Gumbob, D. The prevalence of planning and management frameworks for trees and green spaces in urban areas of South Africa. Urban For. Urban Green. 2015, 14, 817-825. [CrossRef]

(C) 2019 by the authors. Licensee MDPI, Basel, Switzerland. This article is an open access article distributed under the terms and conditions of the Creative Commons Attribution (CC BY) license (http://creativecommons.org/licenses/by/4.0/). 